Loyola University Chicago, School of Law

LAW eCommons

Faculty Publications \& Other Works

2021

\title{
Oral Argument in The Time of Covid: The Chief Plays Calvinball
}

Matthew Sag

Loyola University Chicago, School of Law, msag@luc.edu

Tonja Jacobi

Northwestern University

Timothy R. Johnson

University of Minnesota

Eve M. Ringsmuth

Oklahoma State University

Follow this and additional works at: https://lawecommons.luc.edu/facpubs

Part of the Courts Commons

\section{Recommended Citation}

Tonja Jacobi , Timothy R. Johnson, Eve M. Ringsmuth \& Matthew Sag, Oral Argument in the Time of COVID: The Chief Plays Calvinball, 30 S. CAL. Interdisc. L.J. 399 (2020).

This Article is brought to you for free and open access by LAW eCommons. It has been accepted for inclusion in Faculty Publications \& Other Works by an authorized administrator of LAW eCommons. For more information, please contact law-library@luc.edu. 


\title{
ORAL ARGUMENT IN THE TIME OF COVID: THE CHIEF PLAYS CALVINBALL
}

\author{
TONJA JACOBI*, TIMOTHY R. JOHNSON**, EVE M. RINGSMUTH**, AND \\ MATTHEW SAG****
}

\begin{abstract}
In this Article, we empirically assess the Supreme Court's experiment in hearing telephonic oral arguments. We compare the telephonic hearings to those heard in person by the current Court and examine whether the Justices followed norms of fairness and equality. We show that the telephonic forum changed the dynamics of oral argument in a way that gave the Chief Justice new power, and that Chief Justice Roberts, knowingly or unknowingly, used that new power to benefit his ideological allies. We also show that the Chief interrupted the female Justices disproportionately more than the male Justices and gave the male Justices more substantive opportunities to have their questions answered.

This analysis transcends the significance of individual cases. The fact that the Court experimented with telephonic oral argument, the way it did so, and how the practice could be improved are all issues of profound national importance. The new format had the potential to influence the outcome of cases that have broad national significance, to shift norms of equality and transparency in the Court, and more generally to affect judicial legitimacy. If the Court favors certain parties or certain ideological camps by its choice of forum in a time of crisis, then that will undermine not only the Court's legitimacy but also raise doubts as to whether any of our national institutions have the capacity to adapt to crises.
\end{abstract}

\section{INTRODUCTION}

In May 2020, in response to the global coronavirus pandemic, the U.S. Supreme Court heard oral argument via telephone conference in ten select cases still pending in the October 2019 Term. ${ }^{1}$ After initially delaying hearing cases when it was unclear how long the pandemic would last, ${ }^{2}$ it soon became apparent that the Court had to find a means of addressing at least those cases that were most pressing -including those potentially affecting the 2020 presidential election-and those with greatest legal and political

* Northwestern University.

** University of Minnesota.

*** Oklahoma State University.

**** Loyola University Chicago

1 Media Advisory Regarding May Teleconference Argument Audio, SUP. CT. U.S. (Apr. 30, 2020), https://www.supremecourt.gov/publicinfo/press/pressreleases/pr_04-30-20.

${ }^{2}$ See infra Part I.B. 
significance. ${ }^{3}$ When institutions around the world were switching to technologically sophisticated and highly interactive peer-to-peer videoconferencing to carry out normal duties during a highly abnormal time, ${ }^{4}$ the Supreme Court's choice to conduct oral argument over the antiquated technology of the telephone was typically quaint for this slowmoving institution. ${ }^{5}$ And yet that choice constituted a radical change. The seemingly modest shift to telephonic arguments and the decision to allow the Justices to speak in order of seniority dramatically shifted power away from the ideologically diverse Associate Justices toward the conservative Chief Justice. This shift in power was the result of a decision by the Chief, not the Court as a whole. ${ }^{6}$ In this Article, we show that Chief Justice Roberts consistently employed his new power in a way that was highly unequal, advantaging conservative allies and promoting his conservative agenda. We also show that, in some respects, he used his discretion to advantage the male Justices over the female Justices.

In the May telephonic hearings, the Court grappled with issues ranging from Congress's ability to subpoena the President's tax records, ${ }^{7}$ to employers' religious rights under the First Amendment, and to states' abilities to control presidential electors. ${ }^{9}$ Those cases were important, but the institutional change those hearings represented may be more important: how institutions respond to moments of crisis reveals society's core values and priorities, and shapes our identity going forward. Put simply, whether and how public institutions continue to function in a crisis, such as the current pandemic, is both revelatory and constitutive of our national identity. The telephonic oral arguments are worthy of study as an exemplar of how a vital institution of government adapted to what may be an ongoing crisis.

${ }^{3}$ The majority (twenty) of the cases still pending at the outbreak of the pandemic were held over until the next Term. The cases selected for telephonic hearings were widely regarded as among the most important. See, e.g., Adam Liptak, The Supreme Court Will Hear Arguments by Phone. The Public Can Listen In, N.Y. TIMES (Apr. 20, 2020), https://www.nytimes.com/2020/04/13/us/politics/supreme-courtphone-arguments-virus.html (describing the ten cases chosen for the telephonic forum of the thirty that remained pending as "includ[ing] most of the major ones."). For specifics on individual cases, see infra notes $7-9$.

${ }_{4}$ Zoom has become the standard-bearer of remote working. See, e.g., Jordan Novet, Why Zoom has Become the Darling of Remote Workers During the COVID-19 Crisis, CNBC (Mar. 21, 2020, 12:17 PM), https://www.cnbc.com/2020/03/21/why-zoom-has-become-darling-of-remote-workers-amid-covid-19outbreak.html; Supantha Mukherjee \& Akanksha Rana, Zoom Takes Lead over Microsoft Teams as Virus Keeps Americans at Home: Apptopia, REUTERS (Mar. 31, 2020 11:20 PM), https://www.reuters.com/ article/us-health-coronavirus-zoom-idUSKBN21I3AB. This includes courts, such as the Texas Supreme Court. Marcia Coyle, 'Zooming'on Oral Argument Alternatives, NAT'L L. J.: SUP. CT. BRIEF (Apr. 8, 2020, 7:00 AM), https:/www.law.com/supremecourtbrief/2020/04/08/12-firms-21-companies-and-onelead-counsel-will-the-court-embrace-video-abortion-and-covid-19-on-the-courts-doorstep (reporting that the Texas Supreme Court is using videoconferencing and querying why the Supreme Court Justices cannot adapt to do the same)

${ }^{5}$ See Improvement in Telegraphy, U.S. Patent No. 174,465 (issued March 7, 1876).

6 Joan Biskupic, Behind Closed Doors During One of John Roberts'Most Surprising Years on the Supreme Court, CNN (July 27, 2020), https://www.cnn.com/2020/07/27/politics/john-roberts-supremecourt-liberals-daca-second-amendment/index.html (reporting that the Chief unilaterally decided on the forum and rules of the telephonic oral argument, over some objections of the other Justices).

${ }^{7}$ Trump v. Mazars, 140 S. Ct. 2019 (2020); Trump v. Vance, 140 S. Ct. 2412 (2020).

${ }^{8}$ Little Sisters of the Poor Saints Peter \& Paul Home v. Pennsylvania, 140 S. Ct. 2367 (2020); Our Lady of Guadalupe Sch. v. Morrissey-Berru, 140 S. Ct. 2049 (2020).

${ }^{9}$ Chiafalo v. Washington, 140 S. Ct. 2316 (2020); Colorado Dep't of State v. Baca, 140 S. Ct. 2316 (2020). 
Moreover, given the significance of Supreme Court decisions in the run up to the 2020 election, any suggestion that Chief Justice Roberts was tilting the playing field in favor of Republicans raises questions about the Court's legitimacy and adds weight to calls for institutional reform at the Supreme Court. ${ }^{10}$ Our empirical analysis demonstrates that, knowingly or otherwise, Chief Justice John Roberts did not use his newfound power in a neutral or evenhanded fashion, and that, contrary to recent commentary, he is certainly not becoming a moderate ${ }^{11}$ or betraying conservatives. ${ }^{12}$

In particular, the telephonic oral arguments were less interactive than the in-person oral arguments, which stymied the ability of the Associate Justices to influence the direction of the arguments, while the Chief Justice gained power. The conservative Justices were the beneficiaries of the new format and discretion exercised by the Chief on a number of different measures: They had more words, spoke for longer, and generally gained influence at the cost of the liberal Justices. There were also significant gender effects from the Chief's discretion to terminate individual Justices' turns at speaking - he interrupted female Justices' dialogues with the advocates significantly more than those of the male Justices, as well as disproportionately interrupting the female Justices themselves, and gave the male Justices more opportunity to pursue their questions to fruition. Overall, despite the seemingly equal formal structure of the Justices speaking in order of seniority at the telephonic arguments, Chief Justice Roberts varied how he treated each Justice's opportunity to be heard, advantaging his allies and disadvantaging his ideological opponents and the female Justices.

The influence of political ideology on the Supreme Court has been wellestablished, ${ }^{13}$ and the oral argument phase is no exception: research shows that as Justices seek information and engage in pre-conference discussion with their colleagues, they do so in ways designed to serve policy goals. ${ }^{14}$ The vast majority of these studies, however, focus on the extent to which each individual Justice is influenced by their own political ideology; ${ }^{15}$ in

${ }^{10}$ See infra Concusion.

1" E.g., Curt Levey, John Roberts Has Gone Full Anthony Kennedy, WASH. POST (July 1, 2020, 6:06 PM), https://www.washingtonpost.com/opinions/john-roberts-has-gone-full-anthony-kennedy/2020/07/ 01/3640fd6a-bbdd-11 ea-bdaf-a129f921026f_story.html (arguing Roberts is, to conservatives, "following in the disappointingly centrist footsteps of previous swing Justice Anthony M. Kennedy.").

${ }_{12}$ See infra Conclusion.

${ }^{13}$ From grants of certiorari, see, e.g., Gregory A. Caldeira, John R. Wright \& Christopher J. W. Zorn, Sophisticated Voting and Gate-Keeping in the Supreme Court, 15 J. L. ECON. \& ORG. 549, 550 (1999) (showing that Justices vote to hear cases more frequently in which their preferred litigant or outcome ultimately wins), to Justices' votes in case outcomes, JEFFREY A. SEGAL \& HAROLD J. SPAETH, THE SUPREME COURT AND THE ATTITUDINAL MODEL (1993) (documenting the "attitudinal model" whereby ideology predicts Supreme Court cases), and opinion writing, see, e.g., Forest Maltzman \& Paul J. Wahlbeck, A Conditional Model of Opinion Assignment on the Supreme Court, 57 POL. RsCH. Q. 551, 561 (2004) (establishing that "Chief Justices are more likely to assign majority opinions to those Justices with whom they are ideologically aligned, but also take into consideration the organizational needs of the Court"), and coalition formation, see infra Part 1.A.

${ }_{14}$ See discussion infra text accompanying note 39.

${ }^{15}$ But note the "panel effects" literature, showing that the ideology of other Justices on a bench also influences judicial behavior. See generally Frank B. Cross \& Emerson H. Tiller, Judicial Partisanship and Obedience to Legal Doctrine: Whistleblowing on the Federal Courts of Appeals, 107 YALE L. J. 2155 (1998) (examining the effect of having a potential dissenting voice with a contrary ideological preference on the majority); Thomas J. Miles \& Cass R. Sunstein, Do Judges Make Regulatory Policy? An Empirical Investigation of 'Chevron', 73 U. CHI. L. REV. 823, 827 (2006) (estimating the effect of the composition of appellate panels in applying Chevron deference). 
contrast, this Article illustrates that the Chief Justice was able to manipulate the institutional forum itself to advantage one political side over another, to hobble the influence of the liberal Justices, and to promote the influence of the conservative Justices. ${ }^{16}$ This finding suggests that Chief Justice Roberts is not a neutral umpire simply "call[ing] balls and strikes," as he claimed he would be ${ }^{17}$ rather, he is making up different rules that apply differently to different Justices according to his ideological affinity with them. In the telephonic cases, the Chief was playing "Calvinball," altering the rules as he went along. ${ }^{18}$

The Article proceeds as follows: Part I provides background to the inquiry, first by introducing the literature showing the importance of oral argument in the Court's decision-making process, which illustrates the significance of examining the effect of the switch to the telephonic forum. It then describes the switch to telephonic oral argument, including the changing role of the Chief Justice. Part II describes our data and methods; the new telephonic context requires novel concepts of understanding judicial behavior at oral argument. We develop new tools for empirically analyzing oral argument and show how utilizing these concepts allows us to answer bigger questions than would otherwise be possible. Part III provides our empirical analysis of the telephonic cases, comparing them to the in-person cases since Justice Brett Kavanaugh was seated in October 2018. ${ }^{19}$ It shows that, despite the seemingly formal equality of the telephonic forum, the arguments were marked by significant inequality among the Justices, imposed in large part by the Chief Justice's choice of when to cut off the Associate Justices' dialogue with the advocates. We show that this inequality was not random. Indeed, the telephonic format and the Chief's influence during it consistently advantaged his conservative allies on the Court to the disadvantage of the liberal Justices, and advantaged the male Justices to the disadvantage of the female Justices. The Chief applied different rules to different Justices and to different topics.

We conclude by addressing two important questions raised by our results. First, we analyze whether Chief Justice Roberts's seeming preferencing of the conservative Justices' agenda is at odds with his recent decisions favoring some liberal causes. We argue that it is not: the Chief is a highly strategic actor playing a long game in a context where the Court's

\footnotetext{
${ }^{16}$ Another study showing that changing an aspect of the structure of oral argument- -albeit not an ideological shift-changes judicial behavior at oral argument is Ryan C. Black, Timothy R. Johnson \& Ryan J. Owens, Chief Justice Burger and the Bench: How Physically Changing the Shape of the Court's Bench Reduced Interruptions during Oral Argument, 43 J. SUP. CT. HIST. 83, 83-98 (2018) (showing that the shift from the Justices hearing oral argument at a straight bench to a curved bench changed judicial interactions because the justices could see one another).

17 Roberts: 'My Job Is to Call Balls and Strikes and Not to Pitch or Bat', CNN.COM (Sept. 12, 2005, 4:58 PM), https://www.cnn.com/2005/POLITICS/09/12/roberts.statement.

is "Calvinball has no rules; the players make up their own rules as they go along .... There [is] only one permanent rule in Calvinball: players cannot play it the same way twice." Calvinball, FANDOM: CALVIN \& HOBBES WIKI, https://calvinandhobbes.fandom.com/wiki/Calvinball (last visited Aug. 1, 2020). We got the idea for this contrast from a Northwestern student, Samuel Young, who used it as a comparison between baseball and Calvinball as applied to the Court in general in a term paper.

${ }^{19}$ I.e., those cases heard between October 9, 2018 and March 4, 2020.
} 
legitimacy is fragile. ${ }^{20}$ Second, we provide some practical direction for how the Court should move forward. A return to normalcy in time for the Supreme Court to resume its regular sittings in October 2021 is uncertain. ${ }^{21}$ Even assuming the best, if the end of the COVID crisis is on the horizon, the pandemic vividly demonstrates the need to address the fragility of key aspects of our social, political, and economic infrastructure. ${ }^{22}$ The Supreme Court should, right now, be making contingency plans for future challenges, such as extreme weather events, terrorist attacks, civil unrest, and other pandemics. In a time of fracturing institutional norms and deep political polarization, reliance on the goodwill and presumed neutrality of the Chief is perhaps unwise. We suggest how the Court can do better than telephonic oral arguments.

\section{BACKGROUND: ORAL ARGUMENT IN THE ROBERTS COURT}

\section{A. Oral Argument}

The U.S. Supreme Court normally sits for oral arguments between the first Monday in October and the last week in April. ${ }^{23}$ At precisely 10 o'clock on argument days, the Justices enter the Courtroom through the red velvet curtains behind the bench. After other business is finished (e.g., orders issued and new members of the bar sworn in), the Chief Justice calls the first case and the petitioner's attorney moves to the lectern and begins their argument with the ubiquitous, "Mr. Chief Justice and may it please the Court." These procedures have been status quo for at least as long as the Court has recorded its oral arguments, beginning in the 1955 Term. ${ }^{24}$ They encapsulate the stability and normalcy of the nation's highest Court. Like almost every other aspect of American life, this stability and normalcy was disrupted by the COVID-19 pandemic in early 2020. A brief overview of the academic

${ }^{20}$ For other evidence of Chief Justice Roberts as a strategic player promoting a generally conservative agenda, see Tonja Jacobi, Obamacare as a Window on Judicial Strategy, 80 TENN. L. REV. 763 (2013) (arguing that every major section of the Chief's opinion in NFIB v. Sebelius was a strategic attempt to maximize conservative goals within the constraint of promoting the legitimacy of the Court in a highly salient and political case).

${ }^{21}$ As of May 9, 2021, the CDC COVID-19 tracker in the United States records 32,481,455 total cases and 578,520 confirmed deaths, with 84.6 cases per 100,000 people in the week prior. COVID Data Tracker: United States COVID-19 Cases and Deaths by State, CTRS FOR DISEASE CONTROL \& PREVENTION, https://covid.cdc.gov/covid-data-tracker/\#cases_casesper100klast7days (last visited May 9, 2021). Daily new case numbers have been decreasing. CŌVID Data Tracker: Trends in Number of COVID-19 Cases and Deaths in the US Reported to CDC, by State/Territory, CTRS FOR DISEASE CONTROL \& PREVENTION, https://covid.cdc.gov/covid-data-tracker/\#trends totalandratecases (last visited May 9, 2021) [hereinafter Trends in Number of COVID-19 Cases]. Although the United States has made great strides in controlling COVID numbers in recent months and has had success with the vaccine rollout, scientists warn that the significant surge in other regions could lead to a resurgence in the United States. See, e.g., Andrew Jacobs, India's Outbreak is a Danger to the World. Here's Why., N.Y. TIMES (May 2, 2021), https://www.nytimes.com/2021/05/02/world/india-covid-variants.html ("Experts say uncontrolled outbreaks like India's also threaten to prolong the pandemic by allowing more dangerous virus variants to mutate, spread and possibly evade vaccines.").

${ }^{22}$ For example, keeping local govemments and the judicial system running, ensuring the social security system is working, and maintaining the health care infrastructure.

${ }^{23}$ Note that Supreme Court Terms typically begin in October and end in April and are referred to by the year in which they commenced. Thus the 2019 Term began in October 2019 and concluded in May 2020 .

24 See generally Argument Transcripts, SUP. CT. OF THE U.S., https:/www.supremecourt.gov/ oral_arguments/argument_transcript/2019 (last visited Aug. 1, 2020). 
literature on oral argument is required to understand the significance of this disruption and of the Court's adoption of telephonic oral argument.

Although journalists and academics pay close attention to individual hearings before the Supreme Court, oral argument as an institution was relatively understudied until recently. ${ }^{25}$ But in the past quarter century, the literature has demonstrated that, even as the amount of time devoted to oral argument has decreased, oral argument remains central to the business of the Court. ${ }^{26}$ By way of overview, it shows that oral argument is an important source of information for the Justices, ${ }^{27}$ and that it also serves a "preconference" role as a forum in which the Justices can learn about each other's views and begin attempts at persuasion and coalition formation. ${ }^{28}$ In addition, the literature establishes that, even if we disregard the content of what the Justices say, their behavior at oral argument reveals a great deal about their voting intentions. ${ }^{29}$ The literature also situates oral argument in a broader social context: the increasing trend toward judicial advocacy in oral argument has been linked to broader trends in political polarization in American society, and the notably higher rate at which female Justices are interrupted reflects still unresolved issues of gender in the rest of society. ${ }^{30}$ Finally, oral argument is the only public aspect of the Supreme Court's decision-making process prior to the announcement of the decisions themselves. As such, the institution of oral argument allows the Court to demonstrate its adherence to fundamental Rule of Law values. ${ }^{31}$

\section{Information and Persuasion}

Supreme Court oral argument is laden with tradition, symbolism, and formality, but that overlay of public spectacle should not obscure the fact that oral argument serves an integral function to the judicial decision-making process. The Justices have access to a substantial amount of information in the form of litigant and amicus briefs. These briefs inform the Justices about the legal merits of various arguments and the policy and strategic implications of potential outcomes. ${ }^{32}$ However, the Justices are passive

\footnotetext{
${ }^{25}$ Early accounts of these proceedings include: Arthur Selwyn Miller \& Jerome A. Barron, The Supreme Court, the Adversary System, and the Flow of Information to the Justices: A Preliminary Inquiry, 61 VA. L. REV. 1187, 1187-1245 (1975); E. Barret Prettyman, Jr., The Supreme Court's Use of Hypothetical Questions at Oral Argument, 33 CATH. UNIV. L. REV. 555, 555-91 (1984); James N. Schubert, Steven Peterson, Glendon A. Schubert \& Stephen L. Wasby, Observing Supreme Court Oral Angument: A Biosocial Approach, 11 POL. \& LIFE SCI. 35, 35-51 (1992).

${ }^{26}$ See infra Part I.A.1.

27 See infra Part I.A.1.

${ }^{28}$ See infra Part I.A.2.

${ }^{29}$ See infra Part I.A.3.

${ }^{30}$ See infra Part I.A.4.

31 See infra Part I.A.4.

${ }_{2}$ E.g., Paul M. Collins, Jr., Lobbyists Before the U.S. Supreme Court: Investigating the Influence of Amicus Curiae Briefs, 60 POL. RSCH. Q. 55, 63 (2007) (showing that amicus curiae briefs influence the ideological direction of the Court's decisions); Pamela C. Corley, The Supreme Court and Opinion Content: The Influence of Parties' Briefs, 61 POL. RSCH. Q. 468, 476-77 (2008) (showing that the language used in the parties' briefs shapes the language of Supreme Court opinions contingent on factors such as the quality of the brief, the brief's ideological compatibility with the Court, and the political salience of the case).
} 
recipients of this information - they do not directly control what the parties include in their briefs.

Oral argument is different: in oral argument, the Justices actively seek out information that they deem relevant to their decision-making task. ${ }^{33}$ The Justices use oral argument to resolve factual ambiguities, to explore the merits of grand ideas and specific legal tests, and to ferret out the policy implications of their potential rulings. ${ }^{34}$ As Justice Harlan put it, "There is no substitute ... for the Socratic method of procedure in getting at the real heart of an issue and in finding out where the truth lies." 35 Even though many Supreme Court decisions may seem inevitable ex post, empirical studies suggest that advocate quality and experience in oral argument affect how the Justices vote. ${ }^{36}$ One explanation of what makes more experienced attorneys more persuasive, at least in part, is that they are better able to reduce the costs that Justices must pay when obtaining information. ${ }^{37}$ That is, the information role of oral argument is important to the Justices, and they value the role of good advocates in facilitating that information gathering.

\section{Pre-Conference}

In addition to gathering information, a substantial literature confirms that Justices use oral arguments as a kind of "pre-conference." use oral argument to learn about each other's preferences, to try to alter each

33 TIMOTHY R. JOHNSON, ORAL ARguments AND DECISION MAKING ON THE UNITEd STATES SUPREME COURT 12-13 (2004) (arguing that Justices use oral arguments to direct the content of the information they obtain when making decisions); Eve M. Ringsmuth \& Timothy R. Johnson, Supreme Court Oral Arguments and Institutional Maintenance, 41 AM. POL. RSCH., 651, 662 (2013) (showing that the Court uses oral arguments as an opportunity to solicit information about Congress and its members, particularly when its legitimacy may be in peril). Information-seeking is the stated purpose of oral arguments. Oral Arguments, SUP. CT. U.S., www.supremecourt.gov/oral_arguments (last visited Apr. 29, 2021) (describing oral arguments as "an opportunity for the Justices to ask questions directly of the attorneys representing the parties to the case, and for the attorneys to highlight arguments that they view as particularly important.").

34 JoHNSON, supra note 33, at 45. Miller \& Barron, supra note 25, at 1187-1245; See Prettyman, supra note 25 , at 555-91. Moreover, former Justices agree with these scholarly assessments. For instance, Justice John Harlan argued that "oral argument gives an opportunity for interchange between Court and counsel" to engage in a joint effort to "search out the truth, both as to the facts and the law." John M. Harlan, What Part Does the Oral Argument Play in the Conduct of an Appeal?, 41 CORNELL L. Q. 6, 7 (1955). Chief Justice Rehnquist posited that oral arguments allow Justices to evaluate counsel's "strong and [] weak points, and to ask ... . some questions [about the case]." William H. Rehnquist, Oral Advocacy: A Disappearing Art, 34 MERCER L. REV. 1015, 1025 (1984); Barry Sullivan \& Megan Canty, Interruptions in Search of a Purpose: Oral Argument in the Supreme Court, October Terms 1958-60 and 2010-12, 2015 UTAH L. REV. 1005, 1028 (suggesting that Justices speak more during oral argument because they now only get one chance to speak during the post-conference, as opposed to two times in the earlier Terms, and so talk to each other at oral argument instead); DAVID C. FREDERICK, SUPREME COURT AND APPELLATE ADVOCACY: MASTERING ORAL ARGUMENT 5-6 (2003) (claiming that oral arguments provide opportunity for conversation between Justices that conferences do not).

${ }^{35}$ Harlan, supra note 34 , at 7.

${ }^{36}$ Timothy R. Johnson, Paul J. Wahlbeck \& James F. Spriggs, II, The Influence of Oral Argumentation Before the U.S. Supreme Court, 100 AM. POL. SCI. REV. 99, 107, 109 (2006) (showing that attorneys with greater experience are more likely to present high quality oral argument and that the relative quality of oral argument influences the Justices' vote choices); Timothy R. Johnson, James F. Spriggs \& Paul J. Wahlbeck, Oral Advocacy Before the United States Supreme Court: Does it Affect the Justices' Decisions? 85 WASH. U. L. REV. 457, 495 (2007) (showing that Justices' votes are responsive to the quality of oral argument and that the responsiveness changes depending on the salience of the case).

${ }^{37}$ See Kevin T. McGuire \& Barbara Palmer, Issue Fluidity on the U.S. Supreme Court, 89 AM. POL. SCI. REV. 691, 691-702 (1995).

${ }^{38}$ Sullivan \& Canty, supra note 34, at 1027 (describing oral argument as increasingly "an opportunity for the Justices to persuade each other"); FREDERICK, supra note 34, at 5-6 (claiming that oral arguments provide opportunity for conversation between Justices that conferences do not). 
other's view of a case, and to engage in preliminary negotiations about the final decision. ${ }^{39}$ The pre-conference role of oral argument is apparent from the archival papers of Justice Lewis F. Powell and Justice Harry A. Blackmun, which indicate that those two Justices listened to their colleagues' comments with an ear towards determining how coalitions might form and particularly how their ideological allies and opponents might vote. ${ }^{40}$ Comments from the Justices over the years also confirm this role of oral argument. For instance, Justice Anthony Kennedy commented, "DDuring oral arguments] the Court is having a conversation with itself through the intermediary of the attorney." 41 Additionally, Justice Antonin Scalia noted, "It isn't just an interchange between-between counsel and each of the individual Justices .... What is going on is also to some extent an exchange of information among the Justices themselves."42

The pre-conference function of oral argument is openly discussed by members of the current Supreme Court. In Chief Justice Roberts's words, "[W] hen we get on the bench it's really the first time we get some clues about what our colleagues think. So we often are using questions to bring out points that we think our colleagues ought to know about."43 Justice Sonia Sotomayor argued that one purpose of oral argument "is for judges to hear what's bothering each other."44 Justice Elena Kagan echoed this view: "There's no doubt ... that part of what oral argument is about is a little bit of the justices talking to each other with some helpless person standing at the podium who you're talking through." 45 The Justices also intervene in oral argument when they think that the argument is proceeding down the wrong path in an effort to keep their colleagues focused on the issues they deem most likely to produce the "correct" outcome. 46

As such, oral argument is now, and has been for some time, an important part of the Court's process that plays not only a direct role in providing information to the Justices, but also an indirect role in shaping the decisionmaking of the Court as a group, enabling the Justices to influence one another

${ }^{39}$ Stephen L. Wasby, Anthony A. D'Amato \& Rosemary Metrailer, The Functions of Oral Argument in the U.S. Supreme Court, 62 Q. J. SPEECH 410, 410-22 (1976) (showing, anecdotally, that Justices speak to one another during these proceedings); RYAN C. BLACK, TIMOTHY R. JOHNSON \& JUSTIN WEDEKING, ORAL ARGUMENTS AND COALITION FORMATION ON THE U.S. SUPREME COURT: A DELIBERATE DIALOGUE 20-21 (2012) (demonstrating how Justices specifically interact with one another during argument sessions, including interrupting one another (chapter 2) and listening to what other Justices say (chapter 3)).

40 JOHNSON, supra note 33; BLACK, JOHNSON \& WEDEKING, supra note 39.

41 Supreme Court Visitors Film (C-SPAN television broadcast Feb. 16, 1998), https://www.cspan.org/video/?100767-1/supreme-court-visitors-film.

42 Upcoming PBS Program on the Supreme Court (C-SPAN television broadcast May 5, 1988), https:/www.c-span.org/video/?2514-1/upcoming-pbs-program-supreme-court (discussing PBS Special, The Honorable Court).

${ }^{43}$ Id.

44 Adam Liptak, Sotomayor Reflects on First Years on Court, N.Y. TIMES (Jan. 31, 2011), $\mathrm{https}: / / \mathrm{www} . n y t i m e s . c o m / 2011 / 02 / 01 / \mathrm{us} /$ politics/01 sotomayor.html. Justice Sotomayor suggests that this process also influences her in the subsequent conference, since "she tailors her own reasoning [during conference] to take account of what she has heard from her colleagues at arguments." Id.

${ }_{45}$ Adam Liptak, A Most Inquisitive Court? No Argument There, N.Y, TIMES (Oct. 7, 2013), https://www.nytimes.com/2013/10/08/us/inquisitive-justices-no-argument-there.html.

46 See Tonja Jacobi \& Matthew Sag, The New Oral Argument: Justices as Advocates, 94 NOTRE DAME L. REV. 1161, 1176 (2019) (quoting Justice Alito). 
and form coalitions. To the extent that the telephonic forum has changed the nature of that interaction by disabling the dynamic nature of the Justices' interchanges with one another and the advocates, ${ }^{47}$ it could alter the judicial decision-making process itself.

\section{Prediction}

Empirical studies have shown that case outcomes and the votes of individual Justices can be predicted based on judicial behavior at oral argument. ${ }^{48} \mathrm{~A}$ number of forms of judicial behavior can be used to predict case outcomes before the Justices have even met at conference. For instance, several studies have shown that the Justices have more to say to the party they end up voting against ${ }^{49}$ - a result that holds whether it is based on word counts, speech turns, or even just comments that adduce laughter from the gallery. ${ }^{50}$ These predictive models have become so reliable that scholars have been able to apply them to other contexts, such as the Australian High Court, where the same "disagreement gap" arises. ${ }^{51}$

Furthermore, studies have shown not only how an individual Justice will vote, but also the likely interaction between the Justices, based on their behavior toward one another at oral argument. For instance, inter-justice conflict at oral argument in the form of interruptions is predictive of future breakdowns in voting agreement. ${ }^{52}$ Similarly, the emotional content of the Justices' words at oral argument can be used to predict voting behavior. ${ }^{53}$

With lives hinging on death penalty determinations and markets ready to fluctuate with the adjudication of valuable intellectual property and tax

${ }^{47}$ See infra Part IV.A.

${ }^{48}$ Timothy R. Johnson, Ryan Black, Jerry Goldman \& Sarah Treul, Inquiring Minds Want to Know: Do Justices Tip Their Hands with Questions at Oral Argument in the U.S. Supreme Court?, 29 WASH. U. J.L. \& POL'Y 241, 256 (2009) (showing that the side that receives more attention from the Justices during oral argument is more likely to lose the case).

${ }_{49}$ The first studies to reach this conclusion were based on very small sample sizes. In a study of ten oral arguments in the October 2002 Term, Shullman noted, among other things, that the Justices generally ask more questions (helpful or hostile) of litigants who went on to lose. Sarah Levien Shullman, The Illusion of Devil's Advocacy: How the Justices of the Supreme Court Foreshadow Their Decisions During Oral Argument, 6 J. APP. PRAC. \& PROCESS 271, 273 (2004). In 2005, John Roberts (who was then a regular Supreme Court advocate) found that $86 \%$ of the time the party receiving the most inquiries from the bench ultimately lost the case in a study of twenty-eight cases. John G. Roberts, Jr., Oral Advocacy and the Re-emergence of a Supreme Court Bar, 30 J. SUP. CT. HIST. 68, 75 (2005). In 2009, Johnson et al. found the same result in a larger more rigorous study. Johnson et al., supra note 48 , at $241-61$. In a 2017 study of every Supreme Court oral argument from the 1960 to 2015 Terms, Jacobi and Sag found that not only do the Justices speak more to the advocates whom they ultimately rule against, but that this "disagreement gap" had been increasing since the mid-1990s, Jacobi \& Sag, supra note 46, at 1226-27.

${ }_{50}$ Tonja Jacobi \& Matthew Sag, Taking Laughter Seriously at the Supreme Court, 72 VAND. L. REV. 1423,1426 (2019).

${ }_{51}$ Tonja Jacobi, Zoë Robinson \& Patrick Leslie, Comparative Oral Argument: What Australia Can Teach Us About the U.S. Supreme Court (and Vice-Versa) (Nw. Univ., Working Paper 2020) (unpublished manuscript) (on file with author) (concluding that the Australian Justices are more active when in opposition to a dominant ideological regime or when facing a likely failure to convince their colleagues in the case at hand).

52 Tonja Jacobi \& Kyle Rozema, Judicial Conflicts and Voting Agreement: Evidence from Interruptions at Oral Argument, 59 B.C. L. REV. 2259, 2260, 2263-64, 2294-95 (2018).

${ }^{33}$ Ryan C. Black, Sarah A. Treul, Timothy R. Johnson \& Jerry Goldman, Emotions, Oral Arguments, and Supreme Court Decision Making, 73 J. POL. 572, 577 (2011) (showing that the side that receives a higher proportion of negative language from the Justices during oral argument is more likely to lose on the merits); see also Bryce J. Dietrich et al., Emotional Arousal Predicts Voting on the U.S. Supreme Court, 27 POL. ANALYSIS 237 (2018) (showing emotional arousal in the Justices' voices provides information about subsequent votes). 
cases, ${ }^{54}$ Court observers closely scrutinize everything for any hint of what will be the likely outcome in a given case, from judicial speeches ${ }^{55}$ to judicial health scares ${ }^{56}$ to potential recusals. ${ }^{57}$ Consequently, it is important to anticipate any change to the institutional form of oral argument that might lead to meaningful shifts in voting patterns.

\section{Oral Argument Reflects Broader Social Forces and Shapes the Court's Legitimacy}

Oral argument at the Supreme Court has a remarkably stable formal structure. There have only been minimal changes to the process since 1955: a gradual reduction in the length of time devoted to oral argument, ${ }^{58}$ and the introduction of the uninterrupted two-minute period for each primary advocate, known as the "two minute rule," introduced in the 2019 Term. 59 Nevertheless, empirical studies have shown that despite this stable form, oral argument at the Supreme Court has changed quite significantly in the last few decades. Tonja Jacobi and Matthew Sag demonstrated that judicial activity during oral argument has increased significantly since the $1960 \mathrm{~s}$, in the sense that "[J]ustices in the modern era interrupt more, speak more, and

${ }^{54}$ For example, Oracle Am., Inc. v. Google LLC, 886 F.3d 1179 (Fed. Cir. 2018), cert. granted, 140 S. Ct. 520 (2019) (No. 18-956), held over until the 2020 Term, is estimated to be worth $\$ 9$ billion and has been described as the "Copyright Case of the Decade." See, e.g., Roger Parloff, Google and Oracle's \$9 Billion 'Copyright Case of the Decade' Could be Headed for the Supreme Court, NEWSWEEK (May 23, 2019, 4:10 PM), https://www.newsweek.com/2019/06/07/google-oracle-copyright-case-supreme-court1433037.html.

${ }_{55}$ See Bill Kenworthy, Judicial Campaign Speech, FreEDOM F. INST., https://www.freedomforum institute.org/first-amendment-center/topics/freedom-of-speech-2/campaign-finance-overview/judicialcampaign-speech https://www.freedomforuminstitute.org/first-amendment-center/topics/freedom-ofspeech-2/campaign-finance-overview/judicial-campaign-speech/(last updated Feb. 2007) (describing the dilemma between, on one hand, promoting public confidence in an impartial judiciary through preventing judges from pre-committing to positions in cases via judicial speeches, and, on the other hand, freedom of speech being essential to democracy).

${ }_{56}$ See, e.g., Alexander Bolton, Ginsburg Health Scare Raises Prospect of Election Year Supreme Court Battle, HILL (Nov. 30, 2019, 12:10 PM), https://thehill.com/homenews/senate/472354-ginsburghealth-scare-raises-prospect-of-election-year-supreme-court-battle ("The recent hospitalization of Justice Ruth Bader Ginsburg following a year of health scares has raised the prospect of a Supreme Court vacancy in an election year and a partisan battle royal that would likely surpass the impeachment fight."); Adam Liptak, Denise Grady \& Carl Hulse, Ginsburg Says Her Cancer Has Returned, but She's 'Fully Able' to Remain on the Court, N.Y. TIMES (July 17, 2020), https://www.nytimes.com/ 2020/07/17/us/justice-ruth-bader-ginsburg-cancer.html ("Justice Ruth Bader Ginsburg, the most prominent member of the Supreme Court's liberal minority, said Friday that she has had a recurrence of cancer, causing a wave of anxiety among Democrats that was not completely assuaged by her assurance that she was undergoing chemotherapy, with 'positive results,' and would remain on the Supreme Court.").

${ }^{57}$ See, e.g., Debra Lyn Bassett, Recusal and the Supreme Court, 56 HASTINGS L. J. 657, 659 (2004) (detailing the intense public interest in whether Justice Scalia would recuse himself after going duck hunting with then Vice President Dick Cheney while a lawsuit against Cheney was pending before the Supreme Court, and Justice Scalia's various defenses of his decision not to do so).

${ }_{58}$ Now, since 1970 , oral argument is one hour, with each side ordinarily permitted thirty minutes. SUP. CT. R. 28(3) ("Unless the Court directs otherwise, each side is allowed one-half hour for argument ... . Additional time is rarely accorded."). From 1925 until 1970, oral argument was generally allotted two hours: one hour per side. See ClARE CUSHMAN, COURTWATCHERS: EYEWITNESS ACCOUNTS IN SUPREME COURT HISTORY 126 (2011). From 1911 to 1925 , each side was permitted one and a half hours. SUP. CT. R. 22(3), (1911) (repealed 1925). Prior to 1911, each side was permitted two hours, or more by special leave of the Court. SUP. CT. R. 26(4), 266 U.S. 653 (1925) (repealed 1928). And before 1849 , arguments were unlimited in duration. SUP. CT. R. 53, 48 U.S. v (1849) (repealed 1858).

${ }^{59}$ See discussion infra note 79. 
leave far less time for the advocates to present their case."60 Their data suggests that this increase in activity hit an inflection point in the mid-1990s, supporting their thesis that increasing judicial advocacy was a byproduct of a sharp increase in political polarization that massively escalated at that time $^{61}$ This suggests that Supreme Court oral argument reflects changes in other political institutions, such as Congress, as well as in changing public attitudes.

In addition, numerous scholars have shown the influence of public opinion on the Supreme Court, indicating that influence flows in both directions: to and from the Court and the public. ${ }^{62}$ And Supreme Court hearings reflect broader societal trends in other, more amorphous cultural ways. As Jacobi and Dylan Schweers demonstrated in their landmark study of interruptions at oral argument, even at the apex of the legal establishment, gender appears to play a role in judicial behavior and interactions. ${ }^{63}$ Jacobi and Schweers showed that between 2004 and 2015, female Supreme Court Justices were consistently interrupted more often than male Justices-up to three times as often in some Terms ${ }^{64}$-mirroring gender roles in other parts of society. ${ }^{65}$

As such, the Supreme Court is influenced by and, therefore, reflects the broader political environment, including public opinion. Even more important than public opinion is the institutionally vital element of public esteem for the Court as an institution. ${ }^{66}$ Oral argument is central in that regard because it is the one part of the Supreme Court's decision-making process that is in any way public or transparent. Every other aspect of that process is

60 Jacobi \& Sag, supra note 46, at 1163.

${ }^{61}$ Id. at $1203,1205,1211$.

${ }^{62}$ Amanda C. Bryan, Public Opinion and Setting the Agenda on the U.S. Supreme Court, 48 AM. POL. RSCH. 377, 383 (2020) (showing that public opinion influences Justices' certiorari votes); Amanda C. Bryan \& Christopher D. Kromphardt, Public Opinion, Public Support, and Counter-Attitudinal Voting on the U.S. Supreme Court, 37 JUST. SYS. J. 298, 311 (2016) (showing that Justices will vote against their preferred outcomes if public support for the Court is low).

${ }_{63}$ Tonja Jacobi \& Dylan Schweers, Justice, Interrupted: The Effect of Gender, Ideology, and Seniority at Supreme Court Oral Arguments, 103 VA. L. REV. 1379, 1460 (2017) (showing even at the Supreme Court, men interrupt more than women and men particularly interrupt women); see also Adam Feldman \& Rebecca Gill, Power Dynamics in Supreme Court Oral Arguments: The Relationships Between Gender and Justice-to-Justice Interruptions, 40 JUST. SYS. J. 173, 173 (2019) (showing women Justices are more likely to be interrupted than their male colleagues); Dana Patton \& Joseph L. Smith, Lawyer, Interrupted: Gender Bias in Oral Arguments at the US Supreme Court, 5 J. L. \& CTS. 337, 338 (2017) (showing gender disparities in advocate behavior at Supreme Court oral argument).

64 Jacobi \& Schweers, supra note 63, at 1437 . They made the same findings looking at individual Terms 1990 and 2002. Id. at 1462-63. Jacobi \& Sag extended the analysis, showing that the same pattern held from 1998 through the 2018 Term. Tonja Jacobi \& Matthew Sag, Justice-to-Justice Interruptions: Gender Versus Ideology?, SCOTUS OA (Aug. 3, 2018), https://scotusoa.com/justice-to-justiceinterruptions-gender-versus-ideology; Tonja Jacobi \& Matthew Sag, Can Supreme Court Culture Change? (unpublished manuscript) (on file with authors); see also Tonja Jacobi \& Matthew Sag, October 2018 Term in Review - Part III (Interruptions), SCOTUS OA (May, 14, 2019), https://scotusoa.com/2018term-interruptions.

${ }_{65}$ See, e.g., Don H. Zimmerman \& Candace West, Sex Roles, Interruptions and Silences in Conversations, in LANGUAGE AND SEX: DIFFERENCE AND DOMINANCE 105, 116 (Barrie Thorne \& Nancy Henley eds., 1975) (studying public conversations between mixed-gendered groups and finding that men were responsible for forty-six of forty-eight interruptions); Lyn Kathlene, Power and Influence in State Legislative Policymaking: The Interaction of Gender and Position in Committee Hearing Debates, 88 AM. POL. SCI. REV. 560, 565, 573 (1994) (showing men disproportionately interrupt women in the state legislative arena).

${ }_{66}$ See, e.g., James L. Gibson, Gregory A. Caldeira \& Lester Kenyatta Spence, Measuring Attitudes Toward the United States Supreme Court, 47 AM. J. POL. SCI. 354, 356 (2003) (explaining the importance of institutional loyalty to the Supreme Court). 
opaque: the Justices select the cases, and they hear, deliberate, and write their opinions on them in secret. ${ }^{67}$ The public spectacle of oral argument is vital to the legitimacy of the Court: it assures the parties in the case at hand that their arguments have been heard and considered. ${ }^{68}$ More broadly, oral argument allows the public to see the Court as an impartial tribunal exploring issues of national importance through a balanced adjudicative process. ${ }^{69}$ Oral argument shows the public that the Court practices Rule of Law valuesparticularly, transparency in decision making and equal consideration of the arguments in a neutral forum. As such, there is an expectation that the Court ought to reflect norms of equality, transparency, and fairness. To the extent that it does not act fairly in regard to its own members, it is hard to expect the public to believe that the Court will act fairly to external parties before the Court.

The key takeaways from this literature are that conventional or in-person oral argument plays an integral role in how U.S. Supreme Court Justices make decisions and is central to the Court's legitimacy. Thus, any change in the form and function of oral argument in response to the coronavirus pandemic has broad institutional significance. The next Section describes the switch to telephonic oral argument, the motivation for that choice of forum, and the immediate consequences of that choice.

\section{B. THE AdOPTION OF TELEPHONIC ORAL ARGUMENT}

On March 16, 2020, the U.S. Supreme Court temporarily suspended oral argument in response to the emerging coronavirus pandemic. ${ }^{70}$ At the time of this initial two-week suspension, fewer than 5,000 Americans had tested positive for COVID-19 and fewer than 100 deaths in the United States had been directly tied to the disease. ${ }^{71}$ Two weeks later, as the number of reported cases climbed to over 270,000 , the Court postponed the hearings scheduled for April as well. ${ }^{72}$ By the end of April 2020, the number of confirmed COVID- 19 cases in the United States had surpassed one million, ${ }^{73}$ the death toll had risen to more than $58,000,{ }^{74}$ and the majority of states were subject

${ }^{67}$ Even compared to other courts, the Supreme Court lacks transparency in its decision-making process. The Court's jurisdiction is largely discretionary and it usually chooses which cases it will hear without explanation. The Justices are not governed by a published code of ethics, and issues such as whether a Justice should recuse him or herself are made on an ad hoc basis. See Barry Sullivan, Law and Discretion in Supreme Court Recusals: A Response to Professor Lubet, 47 VAL. U. L. REV. 907, 912, 914-16 (2013). For a rare glimpse of a behind-the-scenes account of Supreme Court decision making, see, for example, BOB WOODWARD \& SCOTT ARMSTRONG, THE BRETHREN: INSIDE THE SUPREME COURT (1979).

${ }_{68}$ See Jacobi \& Sag, supra note 46, at 1168; Sullivan \& Canty, supra note 34, at 1011

${ }^{69} \mathrm{Jacobi} \&$ Sag, supra note 46, at 1168; Sullivan \& Canty, supra note 34, at 1012.

70 Press Release 03-16-20, SUP. CT. U.S. (Mar. 16, 2020), https://www.supremecourt.gov/ publicinfo/press/pressreleases/pr 03-16-20.

71 Coronavirus Updates from March 16, 2020, CBS NEws (Mar. 17, 2020, 7:39 AM), https://www.cbsnews.com/live-updates/coronavirus-updates-cases-fears-deaths-us-latest-2020-03-16.

72 Press Release 04-03-20, U.S. SUP. CT. (Apr. 3, 2020), https://www.supremecourt.gov/ publicinfo/press/pressreleases/pr 04-03-20.

${ }_{73}$ As of April 30, 2020, the United States had 1,061,638 confirmed cases. Trends in Number of COVID-19 Cases, supra note 21.

${ }_{74}$ Morgan Winsor \& Ella Torres, Coronavirus Deaths 'Likely to Continue to Rise' in Coming Weeks, CDC Says, ABC NEWS (Apr. 28, 2020, 9:23 PM), https://abcnews.go.com/Health/coronavirus-updates- 
to "shelter-in-place" orders. ${ }^{75}$ It was clear by this time that life in the United States would not be returning to normal anytime soon. ${ }^{76}$ It was equally clear that the important business of the Court could not be deferred indefinitely. ${ }^{77}$ Fading hopes of a speedy resumption of normal public activity and the need to resolve at least some of the most salient cases before the November election overcame the Court's reflexive institutional conservatism. On April 28,2020 , the Court announced that it would alter its normal process and hear arguments remotely in thirteen cases (in ten arguments) with Justices and counsel participating via telephone conference. ${ }^{78}$

The Supreme Court clearly needed to act to find an alternative forum for hearing these important cases, but it had choice over how to do so. Its choice in forum had significance beyond simply how it would hear the remaining cases. The Court could have conducted oral argument over videoconference and retained the traditional structure of a sixty-minute argument divided equally between Petitioner and Respondent. Doing so would have permitted the Justices to continue to speak on their own initiative, following a long tradition of dynamic interaction between the Justices and the advocates: until the change of forum, advocates appearing before the Court were subject to interruption and interrogation by any of the Justices at almost any time. ${ }^{79}$

At a point in time when schools, colleges, businesses, and a number of other public institutions were transitioning en masse to videoconference

pandemic-world-listened/story?id=70378215 (reporting more than 58,000 deaths in the U.S. as of April $28,2020)$.

${ }^{75}$ See Sarah Mervosh, Denise Lu \& Vanessa Swales, See Which States and Cities Have Told Residents to Stay at Home, N.Y. TIMES (Apr. 20, 2020), https://www.nytimes.com/interactive/2020/us/coronavirusstay-at-home-order.html (showing thirty states under shelter-in-place orders by March 30, 2020).

${ }^{76}$ Although the Court recognized the need to protect itself from the coronavirus in mid-March of 2020 , the Court's first ruling in relation to the growing health emergency was premised on a seemingly willful disregard of the severity and implications of the pandemic. In Republican National Committee $v$. Democratic National Committee, the Supreme Court granted a stay against a lower court order extending the window for receipt of absentee ballots in the Wisconsin Spring election held on April 7, 2020. Republican Nat'l Committee v. Democratic Nat'l Committee, et al., 589 U.S. (2020). The district court had granted the injunction to safeguard the availability of absentee voting in Wisconsin's spring election in view of the dramatically evolving COVID-19 pandemic. Id. And yet the conservative majority of the Supreme Court saw the situation as not "substantially different" from "an ordinary election," id. at 3, a suggestion that Justice Ginsburg, in dissent, characterized as mind-boggling. Id. at 4 . There is at least some evidence that Wisconsin's failure to postpone its spring election and the Court's stay order increased the spread of the coronavirus in Wisconsin. Chad D. Cotti, Bryan Engelhardt, Joshua Foster, Erik Nesson \& Paul Niekamp, The Relationship Between In-Person Voting, Consolidated Polling Locations, and Absentee Voting on COVID-19: Evidence from the Wisconsin Primary (May 11, 2020) (unpublished manuscript), (available at https://ssm.com/abstract=3597233).

77 See, e.g., Editorial Bd., The Supreme Court on Hold, WALL ST. J. (Apr. 5, 2020, 5:26 PM) https:/www.wsj.com/articles/the-supreme-court-on-hold-11586121994 (arguing that "the Justices may have to consider virtual oral arguments - or even delay their annual summer break.").

${ }_{78}$ Press Release 04-30-20, U.S. SUP. CT. (Apr. 30, 2020), https://www.supremecourt.gov/publicinfo/ press/pressreleases/pr 04-30-20. Note that since some of the cases were consolidated, the Court sat for ten arguments during May 2020.

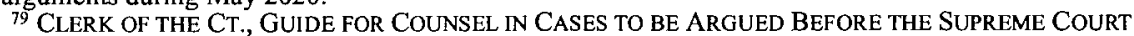
OF THE UNITED STATES, U.S. SUP. CT. 9 (2019), https://www.supremecourt.gov/casehand/ Guide $\% 20$ for $\% 20$ Counsel\%202019_rev10 3 19.pdf. Note that the Court introduced a new guideline for the 2019 Term that advocates would generally be given two minutes of uninterrupted time at the beginning of their presentation. Early data suggested that the rule change had effects beyond the newly established quiet zone. See Tonja Jacobi, Timothy Johnson, Eve Ringsmuth \& Matthew Sag, Look Who's Talking Less: Supreme Court Justices, WASH. POST (Nov. 1, 2019, 3:00 AM), https://www.washingtonpost.com/ outlook/2019/11/01/look-whos-talking-less-supreme-court-justices (suggesting that the two minute rule changed not only how the first two minutes of oral argument were conducted, but impacted the entire hour of oral argument). However, the two minute rule did not fundamentally change the overall character of oral argument as an "exercise in structured disorder." See Jacobi \& Sag, supra note 46, at 1167. 
platforms such as Zoom, ${ }^{80}$ it may seem strange that the Court opted to conduct oral argument via telephone conference. One reason the Court adopted the telephonic format is that the Court has, since the O.J. Simpson trial, sought to avoid televised oral argument. ${ }^{81}$ For decades, the Justices have opposed cameras and other electronic devices in their courtroom for fears the media might misrepresent what the Court does and what the Justices say. ${ }^{82}$ The result, in the Justices' estimation, would be that people exposed to the media's misrepresentations would think poorly of the Court and, consequently, its legitimacy-the ultimate source of its power-would suffer. ${ }^{83}$ For similar reasons, the Justices had also prohibited even live audio streams of oral argument, only agreeing to release audio files at the end of each week under the pressure of public demand. ${ }^{84}$ However, because members of the media could not be physically present at telephonic hearings, the Court altered its rules and-for the first time ever-live streamed the audio to media who could, in turn, stream it publicly. ${ }^{85}$

Thus, while the Court could have joined the rest of world on Zoom with only minimal changes to the oral argument format, it opted instead for a far more radical transformation of oral argument, albeit one effectuated with far more prosaic technology. On Zoom, the Justices could have virtually raised their hands when they wanted to respond to an advocate. In contrast, because the telephone makes the visual cues that are essential to multi-person dialogue impossible, the Court abandoned the freewheeling back-and-forth

${ }^{80}$ Zoom peak daily meeting participants went from less than 10 million in December 2019 to more than 200 million in March 2020 and more than 300 million in April 2020. See Mansoor Iqbal, Zoom Revenue and Usage Statistics (2020), BUS. OF APPS (Mar. 10, 2021), https://www.businessofapps.com/ data/zoom-statistics.

${ }_{81}$ U.S. Supreme Court Appropriations, C-SPAN (Mar. 28, 1996), https://www.c-span.org/video/ ?70835-1/us-supreme-court-appropriations (testimony before House Committee on Appropriations); Richard Wolf, Cameras in the Supreme Court? Not Anytime Soon, USA TODAY (Mar. 7, 2019, 4:52 PM), https://www.usatoday.com/story/news/politics/2019/03/07/justices-alito-kagan-say-video-cameras-haveno-place-supreme-court/3086187002.

${ }_{82}$ For example, Justice Antonin Scalia articulated this concern in October 2006: "If I thought that cameras in the Supreme Court would really educate the people, I would be all for it. But I think it would miseducate and misinform. [ . . ] Nobody's going to be watching that gavel-to-gavel except a few CSPAN junkies." Scalia: From "In Favor" to "Miseducat[ing] and Misinform [ing]", FIX CT. (Feb. 5, 2015), https://fixthecourt.com/2015/02/scalia-favor-miseducate-misinform. He adds, "[F]or every person who watches us from gavel to gavel, there will be 10,000 who will watch a 15 or 30 second takeout on the nightly news .... And I guarantee you that will not be characteristic of what we do." Sahil Kapur, Scalia: Cameras in SCOTUS Would Lead to 'Miseducation', TALKING POINTS MEMO (Apr. 18, 2014, 11:52 AM), https:/talkingpointsmemo.com/livewire/scalia-cameras-in-supreme-court-miseducation. Other current and former justices have made similar remarks. Justice David Souter's experience with cameras in the New Hampshire Supreme Court led him to declare of the Supreme Court: "I think the case [against cameras] is so strong . . that I can tell you the day you see a camera come into our Courtroom, it's going to roll over my dead body." On Cameras in Supreme Court, Souter Says, 'Over My Dead Body', N.Y. TIMES (Mar. 30, 1996), https://www.nytimes.com/1996/03/30/us/on-cameras-in-supreme-courtsouter-says-over-my-dead-body.html.

${ }^{83}$ See Gibson et al., supra note 66 , at 356.

84 See Tonja Jacobi \& Matthew Sag, How SCOTUS Argument Transcripts and Recordings Became Widely Available, SCOTUS OA (January 21,2019), https://scotusoa.com/oyez-history (describing how Chief Justice Rehnquist negotiated with the founder of Oyez.com over whether and how quickly to make transcripts and recordings of arguments available to the public).

85 The Court's practice of providing written transcripts on the day of argument and delaying the release of audio recordings violates the spirit, if not the letter, of various federal disability laws. See, e.g., The Rehabilitation Act of $1973 \S 5008$ (requiring federal agencies to make their electronic and information technology accessible to people with disabilities). 
of traditional oral argument for a series of sequential dialogues between Justice and advocate. In the telephonic oral arguments, each advocate was allowed to speak for two minutes uninterrupted, and then each Justice was given the "opportunity to ask questions" in order of seniority. ${ }^{86}$ The Court's press release did not explicitly say that the Justices would each be given an equal opportunity for dialogue with counsel, but this was widely assumed. ${ }^{87}$

As we explain in more detail in Part III, changing from an open conversation to a hierarchical sequence of two-person dialogues had multiple downstream effects on oral argument ${ }^{88}$ It made arguments longer, decreased the frequency of interruption, and allowed the advocates to speak slower and in longer sentences. ${ }^{89}$ Subjectively, it made oral argument less dynamic and less intellectually engaging. Ideas were not pursued to their logical conclusion and topics were not fully explored, as Justices were limited in the number of interactions they had with each advocate and were often cut off from exploring follow-up inquiries. This loss of dynamism was not simply an unfortunate loss of entertainment value: it reflected a significant impairment in the ability of the Associate Justices to fully engage with the advocates. ${ }^{90}$

The flipside of that loss of influence by the Associate Justices points to the second important implication of the decision to convert oral argument into a hierarchical sequence of seriatim dialogues: it transformed the Chief Justice from merely the "first among equals" to something akin to an orchestra conductor or a tyrannical dinner party host. ${ }^{91}$ Until recently, Chief Justice Roberts would only occasionally intervene to dictate the tempo of conversation or announce whose turn it was to speak..$^{92}$ Typically, he would only do so when one Justice had interrupted another in a way that hijacked the conversation. ${ }^{93}$ However, telephonic argument necessitated someone to announce when one dialogue ended and another began. Logically, that someone was the Chief. The Chief Justice's central role in controlling who

86 Press Release 04-28-20, U.S. SUP. CT. (Apr. 28, 2020), https://www.supremecourt.gov/ publicinfo/press/pressreleases/pr_04-28-20.

${ }^{87} \mathrm{Id}$.

${ }^{88}$ See infra Part IV.A.

${ }^{89}$ Also, this would not have happened on Zoom: "Justice Breyer: Yeah, thank you. I'm sorry. The telephone started to ring, and it cut me off the call. And I don't think it was a robo-call. (Laughter.)" Transcript of Oral Argument at 56, Barr v. Am. Ass'n of Pol. Consultants Inc., 140 S. Ct. 2335 (2020) (No. 19-177).

90 That any loss of dynamic interaction is of concern to both the Justices and the advocates is apparent from the critical reaction to the introduction of the new two minute rule, discussed supra note 79 . Justice Elena Kagan said she's been "watching these people try to fill up two minutes of time without being interrupted, and thinking, we should just do them a favor and interrupt them." C-SPAN, Justice Elena Kagan on the Supreme Court and the Law (Nov. 18, 2019), https://www.c-span.org/video/?4665051/justice-elena-kagan-supreme-court-law\&start=3130; Jordan S. Rubin \& Kimberly Strawbridge Robinson, Lawyers, Uninterrupted, Adjust to Supreme Court Two-Minute Rule, BLoOMBERG (Jan. 7 , 2020) https://news.bloomberglaw.com/us-law-week/lawyers-uninterrupted-adjust-to-supreme-court-two -minute-rule (reporting that the new rule was well-received by many advocates but relaying negative quotes from "a dozen lawyers who've argued under the new rule so far this term.").

91 Timothy R. Johnson \& Charles Gregory, The Chief Justice and Oral Arguments, in THE CHIEF JUSTICE: APPOINTMENT AND INFLUENCE 154 (Artemus Ward \& David Danelski, eds., 2016) (discussing the Chief Justice's status as first among equals especially during oral argument).

${ }^{92}$ See Tonja Jacobi and Matthew Sag, Can Supreme Court Culture Change? (unpublished manuscript) (on file with authors).

${ }_{93}$ Id. 
spoke and for how long in the telephonic arguments gave him a new source of power. As such, it is worth looking at how he used that power.

\section{The Role of the Chief Justice AT Oral ARgument}

The Chief Justice of the United States has been referred to as holding power "second only to the Presidency of the United States." " Chief Justices begin the Court's agenda setting process, ${ }^{95}$ preside over oral argument, ${ }^{96}$ preside over conference, ${ }^{97}$ and assign opinions when they are in the majority. ${ }^{98}$ However, despite the prestige associated with the position, the power of the Chief is constrained in key ways. For one, there are few things Chiefs can accomplish unilaterally. Indeed, important decisions such as granting certiorari and setting precedent require a coalition of Justices. ${ }^{99}$ For another, there are many powers that other chief justices possess that the U.S. Supreme Court Chief Justice does not have, such as choosing which justices sit on a case. ${ }^{100}$

Prior to the recent telephonic hearings, Chief Justice Roberts had been seen as relatively light-handed in his control of oral argument, especially compared to his predecessor, Chief Justice William Rehnquist. ${ }^{101}$ Early in Chief Justice Roberts's tenure, one commentator noted, "The Rehnquist-toRoberts transition has altered the style of the Court. The atmosphere is more relaxed and the chief justice is decidedly more laid back." 102 In fact, Chief Justice Roberts has been criticized for not acting firmly enough in order to rectify inequalities at oral argument, such as gender differences. ${ }^{103}$ More generally, these insights suggest that how Chief Justice Roberts has carried out the Court's oral argument procedures shapes the Justices' collective

94115 Cong. Rec. 15,179 (daily ed. June 9, 1969) (statement of Sen. Thurmond).

95 LEE EPSTEIN \& JACK KNIGHT, THE CHOICES JUSTICES MAKE 90 (1998) (describing the norm that the Chief Justice speaks first at conference); WALTER F. MURPHY, ELEMENTS OF JUDICIAL STRATEGY 82 (1964) (describing the authority of the Chief Justice).

96 Johnson \& Gregory, supra note 91, at 154

${ }^{97}$ Epstein \& Knight, supra note 95, at 90; David M. O'Brien, Storm Center: The Supreme Court in American Politics 206 (2000) (describing conference procedures).

98 Forrest Maltzman, James F. Spriggs III \& Paul J. Wahlbeck, Crafting LaW on the SUPREME COURT: THE COLLEGIAL GAME 7 (2000) (describing opinion writing procedure); Forrest Maltzman \& Paul J. Wahlbeck, A Conditional Model of Opinion Assignment on the Supreme Court, 57 POL. RSCH. Q. 551, 551 (2004) (describing the Chief Justice's opinion assignment authority).

${ }^{99}$ For an analysis of the power-spreading effect of these two rules, respectively, see Jeffrey R. Lax, Certiorari and Compliance in the Judicial Hierarchy: Discretion, Reputation, and the Rule of Four, 15 J. THEORETICAL POL. 61 (2003) (formally modeling the effect of the Rule of Four in granting certiorari on the relative power of different justices on the Court); Tonja Jacobi, Competing Theories of Coalition Formation and Case Outcome Determination, 1 J. LEGAL ANALYSIS 411 (2009) (formally modeling the effects of different norms of coalition building on the relative power of different justices on the Court).

${ }^{100}$ A power that the Australian Chief Justice possesses. See Jacobi, Robinson \& Leslie, supra note 51 (comparing the powers of the Australian and U.S. Chief Justices).

101 See, for example, how Chief Justice Rehnquist reacted when he thought Justices Scalia and Stevens were out of line in U.S. v. R.L.C., 503 U.S. 291 (1992). Johnson \& Gregory, supra note 91, at 167.

${ }^{102}$ Michael McGough, Ardor in The Court; The Chief Justice Gets Rave Reviews For His Un-Stuffy Approach. Will He Take the Next Step: Making the Court More Accessible?, PITT. POST-GAZETTE, Nov. 14, 2005, at B-7 (discussing Chief Justice Roberts's behavior at oral arguments).

${ }_{103}$ Jacobi \& Schweers, supra note 63, at 1485; Feldman \& Gill, supra note 63; see also Timothy R. Johnson \& Ryan C. Black, The Roberts Court and Oral Arguments: A First Decade Retrospective, 54 WASH. U. J.L. \& POL'Y. 137, 140 (2018). 
consideration of a given case: his forbearance has given all the Justices more room to volley with their colleagues, push the attorneys, and, occasionally, ignore them altogether. That changed with the telephonic sessions.

The formal role of the Chief Justice is quite limited during in-person oral argument: his primary authority lies in determining how strictly to enforce the typical thirty-minute time period allocated to each attorney. While he can certainly try to quell an overbearing colleague during oral argument, if that colleague is unwilling to yield the floor then the Chief has little recourse. This stands in stark contrast to the role the Chief defined for himself in the telephonic hearings. Specifically, in the telephonic era, the Chief speaks first after the first two uninterrupted minutes; he then calls on each Associate Justice in order of seniority. ${ }^{104}$ By providing each Justice a dedicated opportunity to pose questions, the new arrangement clearly changed oral argument; most obviously, Justice Thomas, who is well known for his sparse participation in these proceedings, ${ }^{105}$ garnered attention after his repeated engagement with attorneys during the new telephonic argument procedures. ${ }^{106}$

While the new procedure is superficially more equitable in terms of speaking time, its implementation hinges on the Chief Justice in a way that far exceeds traditional oral argument. By endowing the Chief with the authority to determine when to end each Justice's turn and each attorney's answers, the new telephonic oral argument procedure empowered the Chief to shape the content and tenor of the Court's conversation about each case. In other words, the discretion provided to the Chief Justice during telephonic oral arguments allowed for the possibility that his decision to end a Justice's turn would advantage some Justices and viewpoints over others. Such actions would shape the alternatives and information the Court considered as it moved into conference and opinion writing.

We posit that this version of telephonic oral argument gave the Chief Justice new opportunities to behave strategically. Although there were instances of a Justice voluntarily ending his or her turn during the telephonic arguments, ${ }^{107}$ Chief Justice Roberts often interrupted the advocate or Associate Justice who was speaking to transition to the next Justice. ${ }^{108}$ Research on interruptions during traditional oral arguments suggest that the Chief Justice's use of this new authority was not likely to be evenhanded:

104 The change is intuitive, in some sense, because none of the participants (Justices or attorneys) could see one another. Thus, the Court may have reasoned that someone had to call on the speakers to avoid potential chaos and over talk - or so the Court thought. However, several circuits have used telephonic argument or online video sessions with normal procedures, such as the Texas Supreme Court, without having the chief judge call on others to speak. See Coyle, supra note 4.

${ }^{105}$ See Timothy R. Johnson, Maron Sorenson, Maggie Cleary \& Katie Szarkowicz, COVID-19 and Supreme Court Oral Argument: The Curious Case of Justice Clarence Thomas, 21 J. APP. PRACTICE \& PROCESS 113, 125 tbl. 3 (2021) (showing that Thomas has spoken very little during his career but spoke in every case during the telephonic hearings).

${ }_{106}$ Id ; see also Jess Bravin, Supreme Court's First Teleconferenced Argument Heard Live, Is Practically Glitch-Free, WALL ST. J. (May 4, 2020, 3:04 PM), https://www.wsj.com/articles/the-supremecourt-hears-arguments-by-teleconference-amid-coronavirus-pandemic-11588600318; Jeanine Santucci, Supreme Court Justice Clarence Thomas Asks Rare Questions During First Telephone Argument, USA TODAY (May 4, 2020, 1:43 PM), https://www.usatoday.com/story/news/politics/2020/05/04/supremecourt-justice-clarence-thomas-asks-rare-questions-telephone/3078116001.

107 See, e.g., Transcript of Oral Argument at 12, Trump v. Vance, 140 S. Ct. 2412 (2020) (No. 19635). Justice Clarence Thomas ended his questioning of Jay Sekulow with a simple, "Thank you."

${ }_{108}$ See infra Part III-D. 
Jacobi and Schweers found that interruptions between one Justice and another during in-person arguments are gendered and shaped by ideology and seniority during both the Roberts and Rehnquist Courts. ${ }^{109}$ More specifically, women are more likely to be cut off by men, Justices primarily interrupt those ideological opposite themselves, and senior Justices more often interrupt junior Justices. ${ }^{10}$

Jacobi and Schweers's analysis indicates that Justice Sotomayor was the most interrupted Justice - by both male advocates and male Justices. ${ }^{111}$ In the telephonic hearings, it was notable that Justice Sotomayor was repeatedly interrupted by the Chief Justice. In those cases, he repeatedly stepped in to interrupt a specific question and to put an involuntary end to her dialogue with the advocate. For instance, in Trump v. Mazars USA, LLP, Justice Sotomayor was initially interrupted by the advocate and then was cut off in her second attempt to ask a question, this time by the Chief, and only two words in:

JUSTICE SOTOMAYOR: One last question: Was the breadth of these subpoenas litigated below?

DOUGLAS N. LETTER: Yes, Your Honor, those --

JUSTICE SOTOMAYOR: The breadth?

DOUGLAS N. LETTER: -- those -- yes, Your Honor, those exact claims were made and they are discussed in great detail by the Second Circuit and the D.C. Circuit. So those were fully litigated below.

JUSTICE SOTOMAYOR: Breadth or --

\section{CHIEF JUSTICE ROBERTS: Justice Kagan ${ }^{112}$}

The Chief also interrupted Justice Sotomayor later in the same argument, ${ }^{13}$ again in the same way in McGirt ${ }^{114}$ and Chiafalo $v$. Washington, ${ }^{115}$ and twice more in Little Sisters of the Poor Saints Peter and Paul Home v. Pennsylvania. ${ }^{116}$ In Little Sisters, the Chief actually interrupted Justice Sotomayor twice in regards to one line of inquiry. ${ }^{117}$

${ }^{109}$ Jacobi \& Schweers, supra note 63, at 1451 (showing that gender, ideology, and seniority are all statistically significant predictors of interruptions, although seniority is "substantially minuscule," in contrast to ideology and gender).

${ }_{110} \mathrm{Id}$. at 1454.55 (showing that there are statistically significant differences between interruptions by gender, ideology, and seniority, as well as interaction effects between them).

${ }_{111}$ Id. at $1468,1470,1485$ (calling on the Chief to "be more assertive in preventing an interruptereven an interrupting Justice - from continuing his question" or at least subsequently to "give the floor back to the interruptee."). 19-715).

112 Transcript of Oral Argument at 67-68, Trump v. Mazars U.S.A., LLP, 140 S. Ct. 2019 (2020) (No.

${ }_{113}$ Id. at 88.

114 Transcript of Oral Argument at 38, McGirt v. Oklahoma, 140 S. Ct. 2452 (2020) (No. 18-9526).

115 Transcript of Oral Argument at 63, Chiafalo v. Washington, 140 S. Ct. 2316 (2020) (No. 19-465).

116 Transcript of Oral Argument at 20 and 79, Little Sisters of the Poor Saints Peter \& Paul Home v. Pennsylvania, 140 S. Ct. 2367 (2020) (No. 19-431).

${ }^{117} \mathrm{Id}$. at 80. 
Combined, the extant literature-about traditional oral argument, the Chief's role as first among equals on the Court, and the strategic maneuvers available to him with the change to telephonic arguments-leads us to expect that Chief Justice Roberts (and any other Chief) is more likely to cut short the turn of ideologically distant colleagues, of women Justices, and of more junior Justices. These examples suggest that is exactly what happened in the telephonic cases.

But impressions can be misleading; confirmation bias may cause us to notice Chief Justice Roberts interrupting Justice Sotomayor because we know that female Justices and liberal Justices are interrupted more at oral argument. Or it may be the case that Justice Sotomayor was disproportionately interrupted in these cases, but no more so than she generally is in the in-person cases. To truly explore the impact of the choice of the telephonic forum as the Court's response to the COVID-19 pandemic, we need to rigorously compare like with like.

To undertake that analysis, we could of course have just listened to the ten telephonic oral arguments and recounted our impressions. But with such politically salient cases being selected, the cases necessarily involve highly polarized and emotional topics, ${ }^{118}$ so we need an objective basis for analyzing them. We next explain how an empirical approach allows us to do so in a comprehensive analysis of not only the telephonic cases but also of their direct comparators, the in-person cases of the current natural Court (i.e., the 2018 Term and 2019 Term in-person cases).

\section{NEW EMPIRICAL TOOLS}

Determining how to rigorously compare the performance of the Justices to one another in telephonic hearings and to themselves in the in-person cases forced us to rethink the standard empirical tools used to measure activity at Supreme Court oral argument. The empirical literature typically focuses on what the Justices do at oral argument: most commonly, how many times they speak (turns or speech episodes), how many words they say, their tendency

118 Many raised issues potentially directly affecting the upcoming presidential election. See, e.g. Mazars, 140 S. Ct. at 2026 (assessing limits on state investigations of the president and congressional subpoenas of the president); Trump v. Vance, $140 \mathrm{~S}$. Ct. 2412, 2420 (2020) (assessing limits on state criminal investigations of the president), Chiafalo, $140 \mathrm{~S}$. Ct. at 2320 (addressing the constitutionality of faithless electors), Colorado Dep't of State v. Baca, 140 S. Ct. 2316, 2320 (2020) (same). In the more general category of "hot button political issues," there were three religion cases: Little Sisters, $140 \mathrm{~S}$. Ct. at 2372 (addressing the permissibility of a conscience exemption from ACA's birth control requirement); Trump v. Pennsylvania 140 S. Ct. 2367 (2020) (same); Our Lady of Guadalupe School v. MorrisseyBerru, 140 S. Ct. 2049, 2055 (2020) (addressing whether federal courts should hear discrimination claims by teachers at Catholic schools). There were three important commercial cases: Agency for International Development v. Alliance for Open Society International, Inc., 140 S. Ct. 2082, 2086 (2020) (assessing the permissibility of funding requirements for HIV treatment); Barr v. American Ass'n of Political Consultants, Inc., 140 S. Ct. 2335, 2343 (2020) (analyzing debt collection practices); United States PTO v. Booking.com B.V., 140 S. Ct. 2298, 2301 (2020) (examining the applicability of trademark protection for URLs). Arguably this final commercial case was less salient and may have been a "practice round" for the Court. As the first case, it demonstrated the struggles of Justices and advocates as Justice Sotomayor and attorney Erika Ross struggled to get the microphones working at various points. The final case, McGirt v. Oklahoma, $140 \mathrm{~S}$. Ct. 2452 (2020), was effectively a rehearing of an issue that the Court ducked last Term, likely because it would have been decided four-to-four without Justice Kavanaugh yet on the Court. With the outcome potentially affecting the land rights of a huge swath of Oklahoma, and forcing the overruling of potentially thousands of convictions, the Court was understandably reluctant to delay this case again. 
to interrupt and be interrupted, and the frequency of questions as opposed to comments. ${ }^{119}$ This Justice-focused approach worked well in the free-flowing context of in-person oral argument, but it could be quite misleading in assessing the telephonic era in which each Justice is given a certain amount of time to interact exclusively with each advocate. Consider, for example, the question of interruptions. Several studies have examined Justice-toJustice interruptions at oral argument. ${ }^{120}$ However, in the telephonic cases, speaking order was determined by seniority, and the transition from one Justice's time to another's was signaled expressly by the Chief Justice. Given this change in the rules, we did not expect to see-and indeed did not observe - any instances of the Associate Justices interrupting each other in the telephonic hearings.

The problem is not limited to interruptions. Normally, Supreme Court oral arguments run on a strict schedule. Thus, any time used by one Justice to make his or her point necessarily diminishes the time available for other Justices to do likewise. In that context, gauging the intensity of a Justice's participation by counting the number of words spoken makes sense. However, in the telephonic hearings, the Justices' interactions with the advocates are essentially quarantined from each other, and so the relevant question is not how many words a Justice says, but how much time the Justice is allowed for that interaction. Indeed, simply looking at standard measures of the Justices' participation may render misleading results in the telephonic oral arguments.

The argument in Trump v. Mazars is illustrative. ${ }^{121}$ The case addressed the legality of Congressional subpoenas to third parties regarding President Trump's financial activities prior to the presidency. For obvious reasons, this was one of the most politically salient cases of the 2019 Term. ${ }^{122}$ As such, the relative opportunity for participation of the liberal and conservative Justices is highly pertinent. In that case, Justice Ginsburg's first speech episode was 159 words in length-more than double the average speech episode of a Justice in the telephonic cases. ${ }^{123}$ Thus, it might seem on the standard measures that Justice Ginsburg was given a greater chance to be heard in this important and likely highly ideologically divided case. But the Chief Justice interrupted the advocate's answer to Justice Ginsburg midsentence to invite Justice Thomas to speak, and the Chief did not allow Justice Ginsburg another speech episode with that advocate. ${ }^{124}$ In contrast, the Chief allowed Justice Alito two speech episodes with the first advocate

119 See, e.g., Jacobi \& Sag, supra note 46, at 1203-09 (analyzing sixty-five years of oral argument using these measures).

${ }_{120}$ Jacobi \& Schweers, supra note 63. But cf. Black, Johnson \& Owens, supra note 16 at 83, 92-93 (showing, empirically, how the curved shape of the bench significantly decreased the number of interruptions from the bench); Black, Johnson \& Wedeking, supra note 39, ch. 2 (demonstrating the factors that lead Justices to interrupt one another during oral arguments).

121 Mazars, $140 \mathrm{~S}$. Ct. at 2019.

122 For instance, SCOTUSBlog listed the case as one of the eleven "major cases" of the Term. Term Snapshot, October 2019 Term, SCOTUSBLOG (on file with the author).

${ }^{123}$ See infra Table 1.

124 Subsequently, each Justice was permitted another chance to speak in the argument, but this was also not distributed fairly. See infra note 157. 
in Mazars, which were 40 and 56 words, respectively. Looking simply at word count, one would conclude that Justice Alito had only $60 \%$ of the speaking opportunity than did Justice Ginsburg in this part of the hearing. However, the advocate was permitted 197 and 141 words, respectively, to address Justice Alito's issues of interest but only 174 words to respond to Justice Ginsburg. As such, Justice Alito was effectively given 30\% more opportunity for dialogue with the advocate than Justice Ginsburg was granted.

Given the serial dialogue format of telephonic oral argument, we believe the best way to measure each Justices' share of the oral arguments is to focus on their opportunity for dialogue with an advocate, rather than simply the number of words a Justice said, or the number of seconds they took to say them. Relative opportunity for participation is important because, to the extent these opportunities are unequal, the representation of ideas and arguments before the Court was also unequal. In contrast, how a Justice chooses to divide their allotted time between speaking and listening says relatively little about the equality of the presentation of ideas during the argument. For instance, if one Justice asks three quick questions and gets three quick answers from an advocate, and another Justice makes one long speech and gets one short answer from an advocate, how do we compare these two interactions? It is possible that both interactions may take the same amount of time, in which case the Justice making the long speech will measure as more active, having had more words and a longer duration in their individual activity levels. But, arguably, that interaction is not as substantive as the Justice who speaks fewer words but who has multiple interactions with the advocate.

Consider two different approaches in June Medical Services v. Russo. ${ }^{125}$ Justice Sotomayor asked a long question, thereby using many words, when she asked about hospital admitting privileges for doctors. However, she obtained a relatively short response from counsel:

JUSTICE SOTOMAYOR: That -- that's a great example, because he's the doctor who does only medical abortions, not surgical. He hadn't done a surgical procedure for over 12 years. And your state's own expert testified that it was not likely that he was going to get privileges anywhere because he only did medical procedures, never saw a patient. In virtually all of the hospitals, if not all of them, even if there wasn't -- like in Tulane, even if there wasn't a minimum number of patients that had to be admitted before you got privileges, you had to see a certain number of patients in the hospital per year to maintain your privileges. And he couldn't meet that requirement. So you talk about him applying to only one hospital in a situation where it was guaranteed that he couldn't meet the requirements of any hospital.

125 Transcript of Oral Argument at 51, June Med. Servs. L. L. C. v. Russo, 140 S. Ct. 2103 (2020) (No. 18-1323). 
My understanding of hospital practice today is you got to stay alive only if somebody sees patients --

MS. MURRILL: If --

JUSTICE SOTOMAYOR: -- because if they don't see patients, they're of no value to the hospital. If the patients aren't admitted and there's no circumstance in which this doctor is going to admit a patient because he does no surgical procedures --

MS. MURRILL: Justice Sotomayor, I think the record shows that the -- that they can get privileges, they did get privileges, and there's nothing in the bylaws that prohibits them from being ... ${ }^{126}$

In contrast, Justice Alito explored the issue of standing in the same case using a series of short questions that elicited more information:

JUSTICE ALITO: Would you agree with the general proposition that a party should not be able to sue ostensibly to protect the rights of other people, if there is a real conflict of interest between the party who is suing and those whose rights the party claims to be attempting to defend?

MS. RIKELMAN: No, Your Honor, not if that party is directly regulated by the law in question. And, in fact, this Court has allowed third-party standing in cases where the state argued that the third parties were protected by the law and in a sense protected from the plaintiffs.

JUSTICE ALITO: Really? That's amazing. You think that if the plaintiff actually has interests that are directly contrary to those of the -- those individuals on whose behalf the plaintiff is claiming to sue, nevertheless that plaintiff can have standing?

MS. RIKELMAN: If the plaintiff is directly regulated by the law. This Court has allowed an attorney to bring third-party claims against a statute that capped attorneys' fees in favor of clients.

JUSTICE ALITO: Well, that's amazing. Let's -- I mean -- I -- I -suppose -- I know you think that the admitting privileges requirement serves no safety purpose, but suppose that the regulation that was being challenged was one that a lot of people might think really did serve a safety purpose .... ${ }^{127}$

No doubt, the Justices used their time differently because they were trying to make different points, in service of different objectives. The point 
is that it is not possible to meaningfully compare these two types of interactions by counting the words of the Justices alone. In contrast, taking account of the opportunity for dialogue with the advocate afforded to each Justice allows us to assess whether and to what extent the Justices were treated equally.

Operationalizing this concept of opportunity for dialogue in the telephonic cases was relatively simple since, with minor exceptions, the transcripts in those cases proceed through a sequence of Justice-advocate pairs, punctuated by the Chief Justice's "traffic management." 28 However, to make valid comparisons between the in-person and telephonic hearings required sorting the more chaotic in-person hearings into Justice-advocate pairs. To address this, we coded oral argument transcripts using a precise definition of an "interchange" between a Justice-advocate pair." By "interchange," we mean all of the time taken or words spoken between a specific Justice and a specific advocate, by either of them, until a new Justice-advocate interchange begins. Consider the hypothetical sequence: ${ }^{130}$

\begin{tabular}{ll} 
Justice & 1 \\
\hline Advocate & 1 \\
Justice & 1 \\
Advocate & 1 \\
Justice & 2 \\
\hline Advocate & 1 \\
Justice & 1 \\
\hline Advocate & 1
\end{tabular}

Here, the first four speech episodes would constitute a single $J_{1}-A_{1}$ interchange, interrupted by a $J_{2}-A_{1}$ interchange, followed by a second $J_{1}-A_{1}$ interchange. 131 In contrast, when we refer to the "dialogue" between a Justice-advocate pair, we mean the sum total (per case) of all of the interchanges between that particular Justice-advocate pair.

Analyzing Justice-advocate pairs in this way allows us to examine the amount of time each pair interacts and the substantive aspects of these interactions. This is an exacting way to measure participation and permits us to accurately examine one of the most interesting features of these interactions: how they end. ${ }^{132}$ In traditional in-person arguments, it is not unusual for an advocate to finish their answer to a question from one Justice

128 For an explanation and discussion of this concept of traffic management, see infra text accompanying note 167 .

${ }_{129}$ There are minor differences between some of the data presented in this Article and estimates by Leah Litman. Leah Litman, Muted Justice (May 19, 2020) (unpublished manuscript) (available at https://ssrn.com/abstract=3605444). Litman relied on human judgment to determine the beginning and end of what we would call a Justice-advocate interchange in the telephonic era. Our more formal definition leads to results that diverge slightly from Litman's. There are tradeoffs to each approach, but making valid comparisons between the telephonic and in-person oral arguments demands a clear formal definition of what constitutes interchange.

${ }^{130}$ For clarity, we have underlined the speech episodes that begin a new interchange.

${ }_{131}$ Note that we treat a sequence such as $J_{1}, A_{1}, J_{1}, A_{1}, J_{1}, J_{2}, J_{1}, A_{1}$, as a single interchange between $J_{1}$ and $A_{1}$ because the advocate did not respond to $J_{2}$. Note also that an advocate's interruption of a Justice is simply part of the interchange.

${ }_{132}$ See infra Part IV.D. 
only to find another Justice seamlessly presenting another question. ${ }^{133}$ However, it is also quite common during in-person arguments for a Justice to simply interrupt the advocate's answer to someone else's question or for the Justices to interrupt or talk over each other in their rush to ask the next question. By breaking down the arguments into a sequence of Justiceadvocate interchanges, we are able to systematically investigate how the individual interactions between Justices and advocates are terminated and how those interactions compare across telephonic and in-person arguments.

With these tools in hand, we now turn to our empirical exploration of the telephonic cases. ${ }^{134}$

\section{EMPIRICALLY EXPLORING CHIEF JUSTICE ROBERTS'S USE OF HIS NEW AUTHORITY}

In this Part, we present our empirical analysis of the 2019 telephonic cases and compare them to both the 2019 cases heard in-person, as well the 2018 cases heard since Justice Kavanaugh joined the Court. We begin with descriptive statistics concentrating on the structural differences between telephonic and in-person oral argument.

\section{A. Structural DiffERENCES BetWEen TELEPHONIC AND IN-PERSON ORAL ARGUMENT}

To explore the significance of the Supreme Court's new format for remote oral argument, we constructed a dataset derived from the transcripts of Supreme Court oral arguments in the 2018 and 2019 Terms. Our data comprises 123 cases in total: 65 from 2018, 48 from in-person oral argument in 2019 and 10 from the telephonic oral arguments. 135 In these 123 cases, there were almost 30,000 speech episodes and more than 1.3 million words spoken by the Justices and advocates. Table 1 provides the descriptive data at the highest level of aggregation.

133 Experienced advocates know not to pause at the end of a sentence if they have something else they want to say.

134 For each of the analyses below, we replicate the analysis looking only at the behavior of the Justice, rather than the interaction between the Justice and the advocate. For instance, instead of examining interchanges, we examine the number of turns of each Justice not including the time in which the advocate responds to each Justice. The results (available from the authors) are the same. We only present the results of the pair analysis because we believe this is a better way of analyzing oral argument in general and particularly in the artificial structure of the telephonic arguments.

${ }_{135}$ We include only cases from the fourth natural Roberts Court-i.e., only those cases heard after Justice Kavanaugh joined the Court in October 2018. This excludes the first six of the seventy-one cases argued in the 2018 Term. 
Table 1: Aggregate descriptive data

\section{Words Minutes Minutes Words}

\section{Era Cases Turns (total) (total) (mean) (mean)}

$\begin{array}{rrrrrrr}\text { Telephonic } & 10 & 2,170 & 134,885 & 851 & 85 & 13,489 \\ \begin{array}{r}2019 \text { In- } \\ \text { person }\end{array} & 48 & 11,523 & 520,994 & 2,937 & 61 & 10,854 \\ \begin{array}{r}2018 \text { In- } \\ \text { person }\end{array} & 65 & 15,436 & 691,137 & 3,911 & 60 & 10,633 \\ \text { All cases } & 123 & 29,129 & 1,347,016 & 7,700 & 63 & 10,951\end{array}$

Despite Chief Justice Roberts's considerable efforts to move them along, the telephonic hearings were on average $40 \%$ longer than the in-person hearings from 2018 and 2019 (differences are highly statistically significant, $\mathrm{p}<0.01) .{ }^{136}$ The telephonic arguments were also slower than the in-person cases. In the telephonic cases, the Justices spoke at only $84 \%$ of the pace of the 2019 in-person cases and $83 \%$ of the pace of the 2018 cases. ${ }^{137}$ Likewise, the advocates spoke $7 \%$ slower in the telephonic cases than in the 2019 inperson cases and $6 \%$ slower than in the 2018 cases. ${ }^{138}$

This reduction in pace is also reflected in the fewer number of speaking turns per hearing in the telephonic cases ( 217 compared to 240 and 237 turns, on average, in the 2019 and 2018 in-person cases, respectively), despite the fact that the telephonic hearings lasted longer. ${ }^{139}$ On average, there were 2.57 turns per minute in the telephonic forum, compared to 3.91 and 3.93 turns in the 2019 and 2018 in-person arguments (differences are highly statistically significant, $p<0.01$ ) that is, there were only $64 \%$ the number of turns taken in the telephonic cases. Another way of seeing that individual speaking turns lasted longer in the telephonic hearings is to examine the number of words per turn. Compared to the 2019 in-person oral arguments, advocates spoke more than $55 \%$ additional words per turn in the telephonic cases; whereas in

136 Highly statistically significant means the p-value is less than 0.01 ; that is, we can be confident that the chance of this relationship showing as a result of random error is less than $1 \%$. The standard benchmark for statistical significance is a p-value of less than 0.05 ; that is, there is less than a $5 \%$ chance of random error creating the result. We use these two terms throughout the analysis.

${ }^{137}$ The Justices spoke at 2.30 words per second in the telephonic hearings; in contrast, they spoke at 2.71 and 2.73 words per second, respectively, in the 2019 and 2018 in-person cases (differences are highly statistically significant, $\mathrm{p}<0.01$ ).

${ }_{138}$ The advocates spoke at 2.88 words per second in the telephonic cases; in contrast, they spoke at 3.11 and 3.08 words per second, respectively, in the 2019 and 2018 in-person cases (differences are statistically significant, $\mathrm{p}<0.05$ ).

139 P-values are not informative to assess the statistical significance of this difference due to the multiple ways in which the groups have to be split in order to run this test. Whereas ordinarily we are comparing Justice behavior among different groups, e.g. mean duration of liberal Justices versus conservative Justices, and have a large number of observations, when we are comparing the difference in duration for each Justice between two eras, then our observations are only equal to half of the number of Justices. As such, it is appropriate for the reader to assess whether the difference is substantially significant or not, a question of judgment rather than statistics. 
the same comparison, the Justices spoke $23 \%$ more words per turn. ${ }^{140}$ The increase in the number of words per turn does not mean that the participants spoke more quickly; rather, it means they spoke longer before either finishing their point or before being interrupted.

Each of the measures discussed above is consistent with the general observation that, on average, the telephonic oral arguments lacked the dynamism of traditional in-person oral argument. However, it is important to look beyond averages and explore variation before taking these conclusions to the bank - one can still drown in a river that is, on average, only three feet deep. ${ }^{141}$ Figure 1 illustrates the total duration of each argument in the 2019 Term, as well as how that time was divided between the Justices and the advocates. It is apparent at a glance that although there is variation within the telephonic cases, those cases as a group are different from the in-person oral arguments. ${ }^{142}$

140 Advocates spoke an average of 97 words per turn in the telephonic hearings and only 66 and 64 in the 2019 and 2018 in-person oral arguments, respectively (differences are highly statistically significant, $\mathrm{p}<0.01$ ). The Justices spoke an average of 37 words per turn in the telephonic hearings, 30 in the rest of the 2019 Term and 31 in the 2018 Term (differences are highly statistically significant, $p<0.01$ ).

${ }^{141}$ Nate Silver, The Signal and The Noise 179 (2012).

${ }_{142}$ Interestingly, there was no statistically significant difference between the telephonic and in-person hearings in terms of the ratio of advocates speaking to Justices speaking. In words, the advocates spoke between $64 \%$ and $66 \%$ of the total in each era; in terms of the duration, the advocates accounted for between $61 \%$ and $62 \%$ of the total in each era. 
Figure 1: Duration of oral argument 2019 Term by case

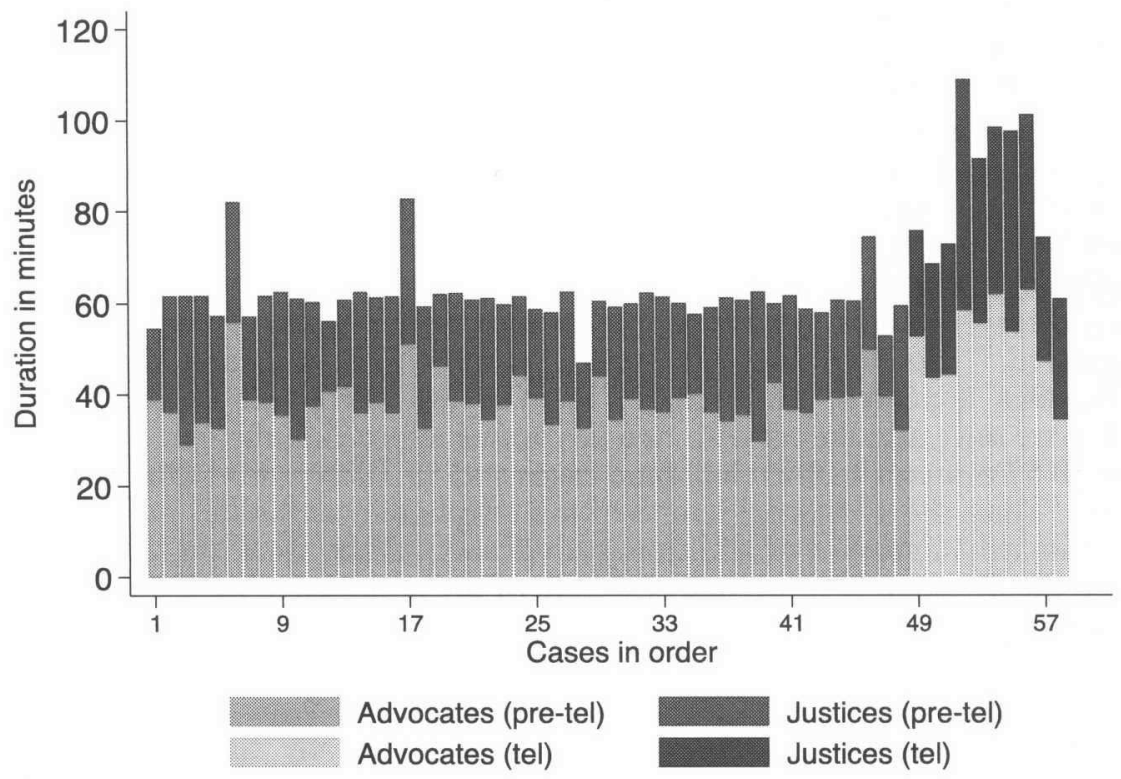

The $\mathrm{x}$-axis presents the 2019 Term cases in the order they were argued and divides each case between advocates' speaking time (below in lighter gray) and Justices' speaking time (above in darker gray). On the right are the final ten telephonic cases with slightly more divergent shading. ${ }^{1}$

Note, first, that the increase in the length of the oral argument during the telephonic cases is consistent and significant. This highlights the effect of different institutional structures: the shortest oral argument in the telephonic era was longer than the average case in the in-person era. Ordinarily, oral argument is set for an hour except where the Court provides for extra timetypically in cases with multiple advocates or when a case is particularly important to the public. In the 2019 term in-person cases, there were three outliers, which ranged from $20 \%$ to $38 \%$ over the normal length. ${ }^{144}$ But there are two important points to note about these outliers: First, two of these cases had four advocates and one had three advocates. ${ }^{145}$ Second, all three of these cases had prespecified time extensions due to their complexity and the

143 Since the 2018 and 2019 in-person cases are quite similar, we ordinarily only graph the 2019 cases, here and elsewhere, except where there is meaningful difference between the 2019 and the 2018 Terms.

${ }^{144}$ Financial Oversight and Management Board for Puerto Rico v. Aurelius Investment, LLC, $140 \mathrm{~S}$. Ct. 1649 (2020) the seventh case heard, lasted 82 minutes; Department of Homeland Security v. Regents of the University of California, $140 \mathrm{~S}$. Ct. 1891 (2020) the eighteenth case heard, lasted 83 minutes; and Seila Law LLC v. Consumer Financial Protection Bureau, 140 S. Ct. 2183 (2020) the forty-seventh case heard, lasted 75 minutes.

${ }^{145}$ Financial Oversight and Management Board for Puerto Rico had four advocates appearing; Department of Homeland Security v. Regents of the University of California had three advocates appearing; and Seila Law LLC had four advocates appearing. 
appearance of additional parties. ${ }^{146}$ All other in-person cases were heard in fewer than 63 minutes, even though thirty-two of the forty-eight in-person cases had more than two advocates appearing.

In contrast, during the telephonic era, only one of the ten cases lasted fewer than 63 minutes-Colorado Department of State $v . B a c a,{ }^{147}$ the final case of the Term, which lasted 61 minutes. All other cases lasted between 69 and 109 minutes, with an average of 85 minutes. These extraordinarily long arguments were not, on the whole, driven by the appearance of additional advocates - in half of those cases only the standard two advocates appeared. $^{148}$ In fact, in both the 2018 and 2019 in-person cases, more advocates appeared, on average, than in the telephonic cases. ${ }^{149}$ If we compare only arguments with two advocates appearing, the average lengths are 70.57 minutes in the telephonic cases and 59.30 minutes in the in-person cases. Thus, the additional length of the telephonic cases does not appear to be primarily a product of additional advocates; rather, the extra length stems from the different institutional structure of the arguments. Institutional rules clearly matter.

The telephonic oral arguments had, in essence, a very different feel from the in-person cases: they lacked the back-and-forth dynamism of the freeflowing arguments in which Justices jump in at any time. Instead, the telephonic cases featured more plodding questioning where the Justices' chance to interact as the argument progressed was limited. We and others think that telephonic cases were far less interesting for spectators due to this lack of dynamism. ${ }^{150}$ But the problem with lack of dynamism is not simply a lack of entertainment. The telephonic format dramatically reduced the ability of the Justices to pose questions directly in response to what the advocate was saying. A Justice who has already spoken or whose time is at an end has no chance to respond to a contentious point, and a Justice who is waiting must continue to wait. This loss of dynamic interaction directly undermines the information-seeking function of oral argument. ${ }^{151}$ This is a significant loss. We imagine, for example, that Justice Ginsburg would have liked to have heard the end of the answer to her question in Trump v. Mazars and may well have seen fit to follow up on the advocate's response. ${ }^{152}$ In the in-person hearings she would have had at least some chance of doing just

${ }^{146}$ See, e.g., Fin. Oversight \& Mgmt. Bd. for Puerto Rico v. Aurelius Inv., LLC, 140 S. Ct. 33 (2019) (extending time of oral argument to 80 minutes).

${ }_{147}$ Transcript of Oral Argument, Colo. Dep't of State v. Baca, 140 S. Ct. 2316 (2020) (No. 19-518).

148 In four cases, three advocates appeared, and in one case, four advocates appeared.

${ }^{149}$ In the telephonic cases, there were on average 2.60 advocates appearing; in the in-person cases, there were 2.71 advocates appearing on average in 2019 , and 2.63 advocates appearing on average in 2018.

iso See, e.g., Jesse Wegman, Live From D.C., It's the Supreme Court!, N.Y. TIMES (May 4, 2020), https://www.nytimes.com/2020/05/04/opinion/supreme-court-coronavirus-telephone.html (describing the first telephonic argument as "a spectacle made for the radio age" and "largely forgettable."). More harsh in its assessment was Lyle Denniston's caustic tweet. Lyle Denniston, @lylden, TwITTER (May 6, 2020), https://twitter.com/lylden/status/1257796446444756996? s=20 ("This harms equal status of each Justice, gives the $\mathrm{CJ}$ arbitrary power, diminishes cross-bench exchanges, promotes wool-gathering by lawyers, prizes order over depth, lets technology triumph, looks amateurish.").

151 See supra Part I.A.1.

${ }^{152}$ See discussion supra note 124. 
that, although she would have been competing with the other Justices for airtime. Presumably, that potential opportunity is preferable to none.

The rules and format of the telephonic oral argument also seem to undermine the "pre-conference" function of oral argument discussed in Part I. ${ }^{153}$ The highly structured nature of the telephonic hearings made it much more difficult for the Justices to talk to each other by posing questions to the advocates. The Justices were unable to jump in with questions at moments where advocates made proposals that were open to critique or to indicate to their colleagues their concerns about weaknesses in a given side of the argument. Instead, they had to wait until their designated opportunity to speak, when often the point was no longer live. ${ }^{154}$

The lack of dynamism and the loss of interaction of the telephonic cases might be a cost worth bearing if the different institutional design brought other benefits, such as greater speaking equality between the Justices. The next two Sections show that although the telephonic forum was more equal on some measures, it essentially substituted one kind of inequality for another. The lack of dynamism in the telephonic arguments goes hand-inhand with the Chief's ability to control the flow of oral argument and to determine whose voices are heard. Accordingly, whereas the inequalities of in-person oral argument result from spontaneous interactions between the Justices, the inequalities of the telephonic hearings primarily reflected the decisions of the Chief Justice.

\section{B. THE BALANCE OF INFLUENCE AMONG THE JUSTICES IN TELEPHONIC AND IN-PERSON ORAL ARGUMENTS}

\section{The Discretion of the Chief Justice}

Ordinarily, the role of the Chief Justice at oral argument is to start and stop the argument, call upon the advocates, and occasionally partake in some gatekeeping when it is unclear who should have the floor. ${ }^{155}$ As discussed, Chief Justice Roberts has been seen as presiding with a light touch in this role $^{156}$ - until the May 2020 argument sessions. The Chief Justice played a much more central role in the telephonic oral arguments; although the order of participation was pre-determined, he controlled when each Justice's time to engage with the advocate would start and when it would stop, unless a Justice voluntarily ended his or her questioning or passed. In the remainder of this Part, we examine in various ways how the Chief Justice used this new authority, whether he used it productively (in ways that furthered the assumed goals of oral argument), and whether he used it evenhandedly.

\footnotetext{
${ }^{153}$ See supra Part I.A.2.

${ }^{154}$ And, consistent with this point, at least one commentator anticipated that the expected "disjointed" nature of telephonic arguments would also disadvantage advocates, as they "may also lose the ability to respond to a hostile question by pivoting to a different point in the hope of engaging a more friendly justice." Adam Liptak, Virus Pushes a Staid Supreme Court Into Revolutionary Changes, N.Y. TIMES (May 3, 2020), https://www.nytimes.com/2020/05/03/us/politics/supreme-court-coronavirus.html.

${ }_{155}$ Scholars have called on the Chief to be more active, for instance, in response to evidence that female Justices are interrupted more than male Justices and male Justices are less likely to recognize an interruption of a female Justice than that of a male Justice. Jacobi \& Schweers, supra note 63, at 148485 .

${ }^{156}$ See supra text accompanying note 101.
} 
The case of Trump v. Mazars ${ }^{157}$ illustrates vividly that the Chief was not always even handed. During the oral argument in Trump v. Mazars, as discussed, ${ }^{158}$ Chief Justice Roberts cut off Justice Ginsburg before she had a chance to ask a second question, or even to have her first question fully answered. Despite having so abruptly cut off Justice Ginsburg, after each Justice had spoken in order of seniority, Chief Justice Roberts announced that there was time left over for additional questioning and declared, "[S]o I think I'll begin with myself, and then we'll go through in order and just see how far we get." ${ }^{59}$ During the additional rounds of questioning in Mazars, the Chief permitted himself four more substantive speech episodes (i.e., not counting traffic management), in which he addressed four different substantive issues: the potential for presidential harassment from multiple committees; ${ }^{160}$ the complication of district attorneys and Congress both subpoenaing the president; ${ }^{161}$ the possibility of the Senate also issuing subpoenas; ${ }^{62}$ and how to measure harassment. ${ }^{163}$ He permitted himself 245 words to pursue multiple additional comments and questions on each topic and permitted the advocate, Douglas N. Letter, 597 to respond to his inquiries. Subsequently, Justice Sotomayor was given a chance to speak. She had one speech episode that was 64 words in length; Letter's response was 66 words in length, which consisted entirely of the advocate correcting a factual assumption in her question. When Justice Sotomayor went to ask a follow-up, she was only permitted 5 words, "[s]o how do we get --", before being interrupted by the Chief. ${ }^{164}$ This contrast was striking, but it is only one anecdote - we can use the power of systematic empirical analysis to assess whether this was an isolated incident or represents a broader trend.

\section{Telephonic Oral Argument Changed the Balance of Participation}

\section{Between the Justices}

On a superficial appraisal, the telephonic forum actually appeared to promote equality among the Justices, as shown in Figure 2. It displays the average number of interchanges per hearing for each Justice in three different groups of cases. Specifically, the left-hand portion of the figure shows the average number of interchanges for each Justice in the telephonic cases; the 2019 and 2018 in-person cases appear, respectively, in the center and right panels. ${ }^{165}$ To highlight the ideological consequences of the shift to telephonic

${ }^{157}$ Trump v. Mazars U.S.A., LLP, 140 S. Ct. 2019, 2019 (2020).

158 See supra text accompanying note 121 . 19-715).

${ }^{59}$ Transcript of Oral Argument at 79, Trump v. Mazars U.S.A., LLP, 140 S. Ct. 2019 (2020) (No.

160 Id.

$161 \mathrm{Id}$. at 80

$162 \mathrm{Id}$.

${ }^{163} \mathrm{Id}$. at $80-81$.

164 Id. at 88 .

${ }^{165}$ The averages reported in Figure 2 are conditional upon a Justice speaking in a case. Accordingly, Justice Thomas's bar is empty in the in-person 2019 cases in which he did not speak, and depicts an average of one interchange in the 2018 cases even though he only had one interchange with an advocate during the entire Term. 
hearings, all of the figures in this Section represent the conservative Justices in dark gray and the liberal Justices in light gray.

We are particularly interested in the extent to which Chief Justice Roberts used his new discretionary power to preference one speaker over another. But if we were to simply count Roberts's turns, words, and duration, we would risk over-counting his contribution due to what we call his "traffic management role" (introducing the case, calling on the advocates or the Justices to commence their speaking slot, etc.). It is important not to disregard these elements, as they are a large part of how the Chief was able to tilt the playing field in a given direction, but it is also important to not count traffic management as part of his substantive participation as a decision-maker. Accordingly, we show both Roberts's substantive contribution and his traffic management, the latter indicated in pale gray. ${ }^{166}$

Figure 2: Average number of interchanges in oral argument ${ }^{167}$
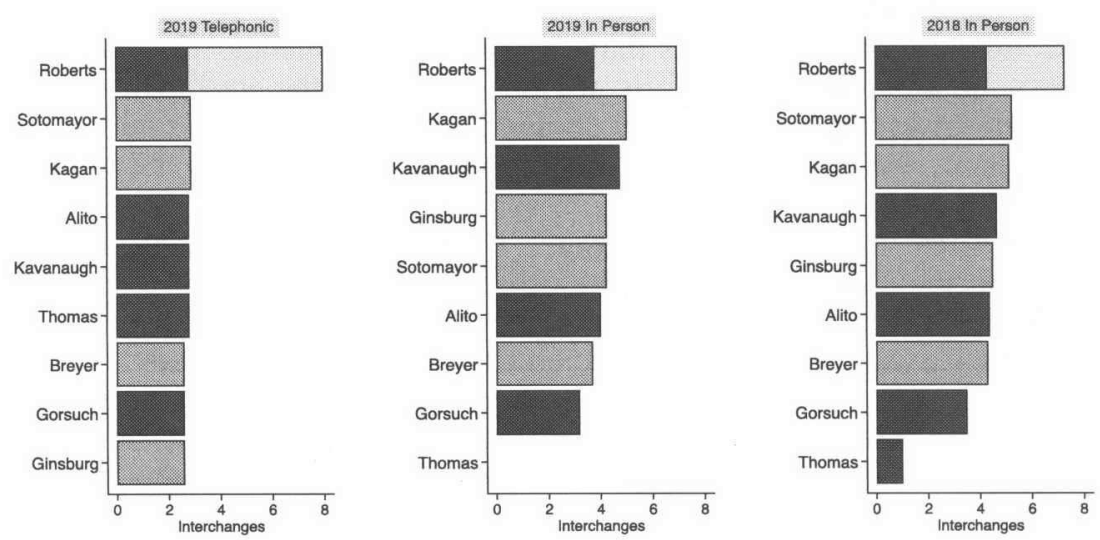

At first blush, the average number of interchanges in the telephonic cases appear far more equal than those in the in-person cases. In the telephonic cases, everyone except Chief Justice Roberts looks almost identical in the average number of interchanges, with the average ranging between 2.60 (Justices Ginsburg, Breyer, and Gorsuch) and 2.89 per case (Justices Kagan and Sotomayor). In contrast, in the in-person cases, there is much more variation, even putting aside Justice Thomas as an outlier, since he rarely speaks in the in-person cases, ${ }^{168}$ but took his turn in every case in the

${ }^{166}$ Although we initially used as an algorithm to make this distinction, we also manually reviewed all of the Chief Justice's speech episodes in the 2018 and 2019 terms to confirm and refine the results of the algorithm.

${ }^{167}$ This figure illustrates the average number of interchanges per argument for each Justice, conditional upon that Justice having spoken. This may overstate Justice Thomas' contributions to the 2018 oral arguments.

168 Jacobi \& Sag showed that between his entry to the Court in 1991, and 2015 (the end of their period of study), Justice Thomas spoke on average only three words per case. Jacobi \& Sag, supra note 46, at 1213 . 
telephonic cases. ${ }^{169}$ Indeed, in 2019 , the average number of interchanges (setting aside Justice Thomas) varies from a low of 3.18 for Justice Gorsuch, to a high of 5.04 for Justice Kagan and, in 2018, the range varies from 3.49 for Justice Gorsuch, to 5.28 for Justice Sotomayor. If instead of analyzing interchanges between pairs, we examine individual Justice's turns (i.e., excluding the time of the advocate in responding to the Justice), the results are substantively identical. ${ }^{170}$

Another element that gives a false impression of equality is that the Chief's substantive interchanges during the telephonic cases mirror those of the other Justices, at 2.80 interchanges, and it is only his traffic interchanges that put him far ahead of the other members of the Court, at 8.00 interchanges. But, it is important to note the extent of this activity by the Chief; he is almost three times as active as the other Justices due to his traffic management role. In contrast, in the in-person cases, his traffic activity constitutes fewer interchanges than the least active Justice who consistently speaks-Justice Gorsuch. While we do not count the traffic management interchanges as substantive, they should not be ignored. As such, Figure 2 makes clear just how dominant was the Chief's presence at the telephonic oral arguments.

Otherwise, in terms of interchanges, the telephonic arguments were more equal. But the simple number of blocs of time that each Justice speaks is a very limited, formalistic measure of equality-it cannot capture how much the Justices each get to say, how much they get to probe the advocates, and how much influence they have on the direction of the argument. The remainder of this Section shows that, on other measures that substantially address those inquiries, the telephonic cases were highly unequal.

We begin this examination in Figure 3, which shows how the telephonic cases compared to in-person arguments in terms of the mean duration of Justice-advocate dialogues for each Justice in each case. ${ }^{171}$ The Justices are ordered from longest to shortest duration. As before, the conservative Justices appear in dark gray, the liberal Justices in light gray, and the time the Chief devotes to traffic management is indicated in the lightest gray. ${ }^{172}$

${ }^{169}$ The significant divergence of Justice Thomas from the other justices in the in-person cases in both 2018 and 2019 (and more generally), as well as how this changed in the telephonic cases, is discussed in detail, infra text accompanying note 105 .

${ }_{170} \mathrm{As}$ is true for all of the results that follow. Results available from the authors.

171 There are different ways to present these data. In this figure we have simply averaged the total duration of each Justice's dialogues in any given case. We could present the average per unique dialogue instead and this would lead to slightly different results where at least one side of the case was represented by more than one advocate. See, e.g., Adam Feldman, Empirical SCOTUS: Results From the Court's Experiment With a New Oral Argument Format, SCOTUSBlog (May 22, 2020, 4:51 PM), www.scotusblog.com/2020/05/empirical-scotus-results-from-the-courts-experiment-with-a-new-oralargument-format. Feldman's results are in line with ours, but he sets aside the Chief Justice's traffic management rather than simply differentiating it from the Chief's substantive engagement.

${ }_{172}$ Another way of measuring effectively the same thing is the number of words spoken-for all of our analysis conducted in terms of duration, we conduct the same analysis in terms of number of words spoken, and the results are consistently very similar. We present our results in the main text in terms of duration rather than words because, while duration and number of words spoken are highly correlated, time is the currency of oral argument. In contrast to the briefs, there is no mandated maximum word count at oral argument; instead, there is a set time limit for each advocate and, ordinarily, for the overall argument. See JOHNSON, supra note 33, Chapter 1 (on the history of oral argument). 
Figure 3: Justice share of oral argument duration, by pair interchanges ${ }^{173}$
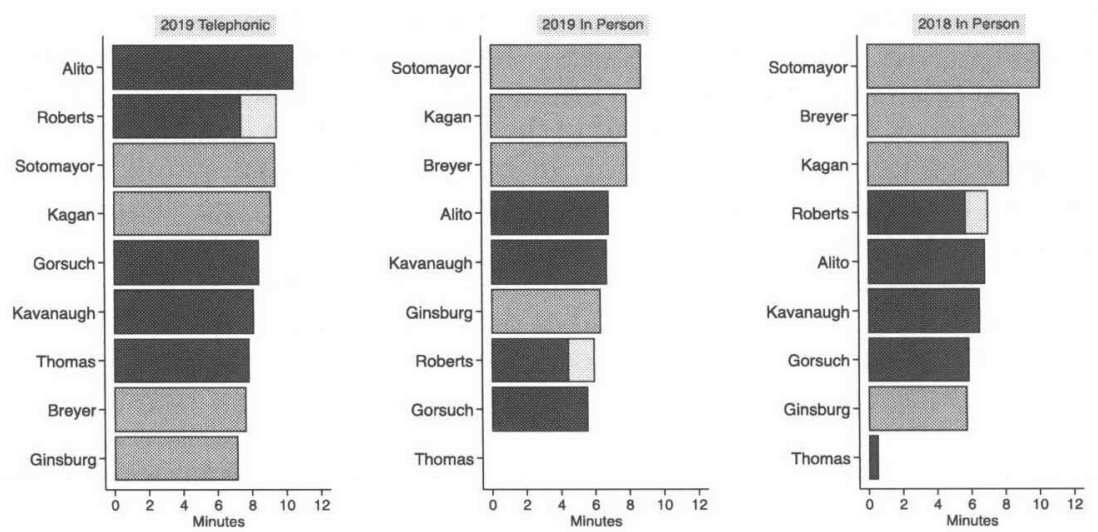

The data presented in Figure 3 indicate that there was a significant shift in the balance of influence between liberals and conservatives in the telephonic hearings compared to the in-person cases in the Court. Jacobi and Sag showed that the out-of-power ideological camp consistently speaks more than the dominant group; for the last fifty years that has meant that the liberal Justices speak more than the conservative Justices. ${ }^{174}$ The opposite took place during the Warren years - when the liberals dominated the Court, the conservatives dominated oral argument. ${ }^{175}$ This is the pattern we see in the middle of Figure 3: in the 2019 in-person cases, there was an almost perfect ideological split between the more active liberal Justices and the comparatively inactive conservative Justices, only disordered by Justice Ginsburg speaking slightly less than Justices Alito and Kavanaugh. The same pattern emerges in the right side of Figure 2 (the 2018 cases); the only difference is that Justice Ginsburg sits considerably lower down the participation rankings, but during that Term she was being treated for, and then recovering from, pancreatic cancer and a fall that broke her ribs.

The telephonic cases (the left side of Figure 3) are quite different. For the first time in the then-current Court, a conservative Justice, Justice Alito, was the most active Justice. ${ }^{176}$ Previously, Justice Alito had been fourth and fifth in this share of argument, respectively, in 2019 and 2018. The benefit to Justice Alito of having the Chief Justice, his close ideological ally, controlling the sessions is apparent. Justices Sotomayor and Kagan continue to have a greater-than-average role in oral argument in the telephonic cases, but they have been eclipsed by Justice Alito, and to some extent by the Chief Justice as well. On the other hand, Justice Breyer is pushed well down the order of Justices in pair-duration, and Justice Ginsburg also moves down

\footnotetext{
173 The average durations reported in Figure 3 are conditional on speaking in a given case. As noted previously, this may overstate Justice Thomas' contributions to the 2018 oral arguments.

174 Jacobi \& Sag, supra note 46, at 1221-23.

175 Id. at $1221-22$.

${ }^{176}$ Chief Justice Roberts comes in second, but this is partly due to his traffic management role in the proceedings.
} 
compared to the 2019 in-person cases (remember that in 2018 she was unusually quiet due to her illnesses). And of course, the most significant change in relative contribution to oral argument was that of Justice Thomas. Justice Thomas did not speak at all in the 2019 in-person oral arguments, and he barely spoke in the 2018 Term. In contrast, in the telephonic cases, he spoke an average of 2.14 minutes per case and his average dialogues with the advocates totaled almost 8 minutes per case. In the telephonic cases, Justice Thomas was no longer an extreme outlier, ${ }^{177}$ although his duration of participation was still at the low end of the range. We address in detail below whether the effect of the telephonic forum of promoting the participation of Justice Thomas constitutes an equalizing force; for now, we simply note that Justice Thomas is one of the conservative Justices whose participation dramatically increased, while the liberal Justices' participation notably decreased.

The data examined above indicate that the shift in format in the telephonic hearings significantly changed the balance of participation between the Justices, as compared to the in-person hearings of 2018 and 2019. In Figure 4, we provide additional evidence of this transformation by considering different ways to measure participation. It shows the relative change between the Justices in their turns, in the relative duration of those turns, and in the difference in words spoken.

177 See, e.g., Garrett Epps, Clarence Thomas Breaks His Silence, ATLANTIC (Feb. 29, 2016), www.theatlantic.com/politics/archive/2016/02/clarence-thomas-supreme-court/471582 ("[N]ot since Clarence Darrow for the defense called prosecutor William Jennings Bryan himself to the stand has an American courtroom been so startled" as when Justice Thomas spoke for the first time in a decade); see also Johnson et al., supra note 105, at 142 (explaining how Justice Thomas significantly affected the telephonic oral arguments). 
Figure 4: Differences in Justices' share of oral argument, winners and losers, by pair interchanges
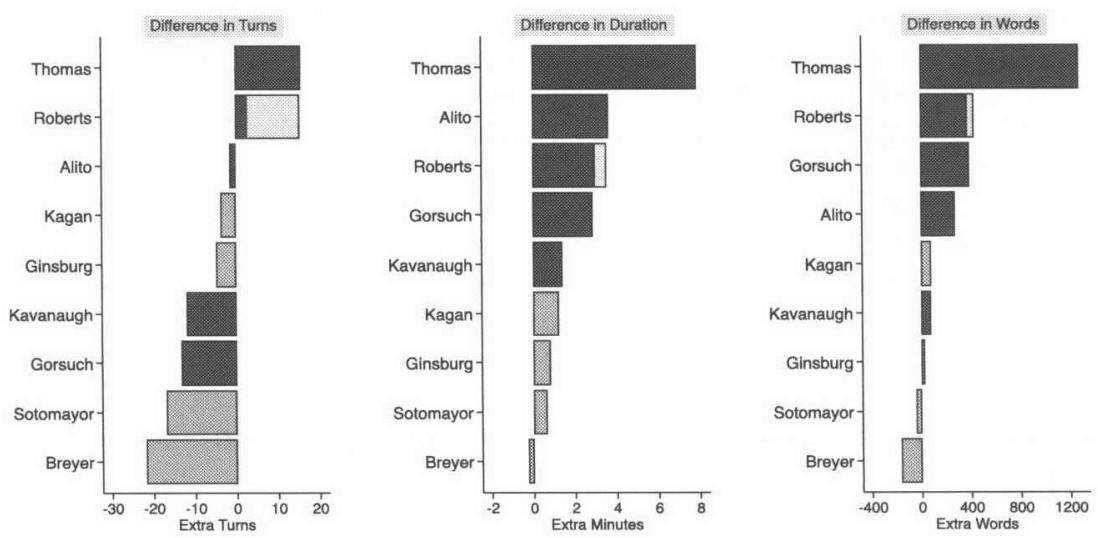

Figure 4 displays the Justices' relative opportunities to participate at oral argument in the telephonic cases compared to the in-person cases from the 2019 Term, measured in the number of speaking turns, duration in minutes, and wordcount. The figure depicts who gained from the transition of telephonic oral argument in terms of those opportunities - the "winners"and who had less such opportunity - the "losers." The calculation is simple: for each Justice, we subtract their participation during 2019 in-person cases from their telephonic participation (results using 2018 in-person cases are substantially identical). ${ }^{178}$ As such, Justices whose bars appear to the right of zero are beneficiaries in the telephonic cases while those whose bars lie to the left of zero participated less in the telephonic cases.

Taking in the figure as a whole, the clear winner from the telephonic cases is Justice Thomas. Of course, this stems from the fact that he did not speak at all in 2019 (and barely spoke in 2018). Apart from Justice Thomas, the only other Justice to consistently gain ground in every category is Chief Justice Roberts. Even discounting his traffic management role, the Chief granted himself more turns, as well as longer duration and more words, in his interactions with the advocates. ${ }^{179}$

More important than any individual Justice's gain or loss of position is the dramatic effect telephonic arguments had on the Court's two ideological camps. In the most important category-duration-there is notable ideological division between those who gained the most and those who lost or gained less, with all conservative Justices considerably benefiting. With much longer argument sessions, all of the Justices gained duration except for Justice Breyer, who lost a very small amount of ground. But the gains for the

\footnotetext{
${ }^{178}$ Once again, we are using the total number of turns, duration, and words from the relevant Justiceadvocate dialogues.

179 As we saw in Part IV.A, both advocates and Justices spoke in longer speaking turns in the telephonic hearings, and thus the total number of turns was greatly reduced. In this context, it is remarkable that the Chief gained ground even in that category. This is a certain sign he enjoyed being more than "first among equals."
} 
other liberal Justices were extremely small, whereas the gains for all the conservative Justices (other than Justice Kavanaugh), were substantial. On average, each conservative Justice received 3.60 more minutes in their interchanges with advocates, whereas the average liberal Justice was granted a mere 0.61 minutes of additional time during the telephonic cases. The same trend holds for words used, although Justices Kagan and Kavanaugh switch places-Justice Kagan spoke faster than Justice Kavanaugh. On average, each of the conservative Justices gained more than 454 words per argument whereas the liberal Justices lost more than 26 words per oral argument. The contrast in terms of the number of speaking turns was not perfectly sorted on ideology, but in aggregate it was highly ideological: comparing the telephonic hearings to the 2019 in-person oral arguments, conservative Justices on average had 1.75 fewer turns, whereas liberal Justices had a whopping 11.78 fewer turns.

The changes in the relative positions of the Justices illustrated in Figure 3 and the winners and losers comparison made in Figure 4 both demonstrate the effect of the change in format from in-person to telephonic argument. Since, most frequently, Justices did not voluntarily cede their time during argument in the telephonic cases, the Chief Justice's decisions about how to exercise his prerogative as master of ceremonies played a large role. In contrast, the participation of each Justice in oral argument during in-person hearings is determined by the Justice's own activism or reticence. In this new paradigm of telephonic arguments, the conservative Justices were much more involved. In other words, there is a clear and consistent ideological impact emanating from the new format. Conservative Justices benefited from this imposed structure and liberal Justices were disadvantaged.

One might be inclined to conclude that the telephonic cases were an equalizing force, if only for incorporating Justice Thomas's participation. However, there are two potential reasons why this characterization may not be the best perspective: First, while many have surmised as to why Justice Thomas remains silent, ${ }^{180}$ as well as to why he occasionally breaks his silence, ${ }^{181}$ there is anecdotal evidence that he simply prefers to let others speak and even to ask his questions for him. ${ }^{182}$ Second, Justice Thomas

${ }^{180}$ Some have said Justice Thomas is simply not paying attention, essentially free riding on the efforts of his colleagues. Jeffrey Toobin, Clarence Thomas's Disgraceful Silence, NEW YOR KER (Feb. 21, 2014), www.newyorker.com/news/daily-comment/clarence-thomass-disgraceful-silence ("These days, Thomas only reclines; his leather chair is pitched so that he can stare at the ceiling, which he does at length. He strokes his chin. His eyelids look heavy. Every schoolteacher knows this look. It's called 'not paying attention." "). Jacobi \& Sag, supra note 46, at 1214 (showing that "for most of the Court's modern history, judicial silence was quite ordinary; what is unusual is not that Justice Thomas is silent, but that now he is the only justice who is silent.").

${ }^{181}$ See, e.g., Richard Primus, The Unexpected Importance of Clarence Thomas, POLITICo (Oct. 4, 2016), https://www.politico.com/magazine/story/2016/10/supreme-court-2016-clarence-thomas-legacy214319 " $C a n$ it be a coincidence that Thomas made his voice heard immediately after Scalia's fell silent?").

${ }^{182}$ Others have noted Justice Thomas's tendency to whisper to Justice Breyer at oral argument. See, e.g., Melissa Quinn, Telephone Arguments Spotlight Usually Silent Clarence Thomas, CBS NEWS (May $7,2020, \quad 10: 21 \quad$ AM), https://www.cbsnews.com/news/clarence-thomas-supreme-court-questionstelephone-arguments ("While Thomas often does not address the lawyers who appear before the Supreme Court, he is active when the justices hear cases in-person, whispering to Justice Stephen Breyer, who he sits beside, and quietly soliciting records from court staff."). 
himself says that he does not like speaking in public generally, ${ }^{183}$ and particularly does not see the point of Justices talking much at oral argument. ${ }^{84} \mathrm{He}$ describes his colleagues as "talk[ing] too much," mostly out of habit, and the advocates as not needing his contribution or that of the other Justices. ${ }^{185}$ As such, it is not clear that Justice Thomas himself necessarily values an explicit expectation that he contribute at oral argument.

Another factor is that while the telephonic forum may have promoted Justice Thomas's participation, it also had other unequalizing effects, as our analysis showed. We believe that Justice Thomas being encouraged to participate is a positive development-even if contrary to his inclinationas it leads to a better representation of diverse voices, and that is particularly important as he is the only African American Justice on the Court. But how do we weigh this gain against the loss of opportunity to participate of the four liberal Justices? It is possible to say that the telephonic structure overall had an equalizing effects if we adopted a Rawlsian "maximin" approach to judicial participation at oral argument, whereby moral good is deemed to be achieved when maximizing the opportunity of those at the bottom. ${ }^{186}$ But unlike Rawls, we are not concerned with addressing ingrained societal problems of entrenched poverty and inequality. ${ }^{187}$ Ultimately, since Justice Thomas ordinarily chooses not to speak at oral argument, due to his disdain for speaking and because he believes his colleagues speak too much, it is difficult to argue that, overall, it makes up for the highly disparate effect of the structure of oral argument whereby the liberal justices are being given less of an opportunity to speak.

More generally, one could argue that the difference in winners versus losers is driven by the fact that the liberal Justices ordinarily participate more at oral argument than the conservative Justices. But it is not at all clear why an artificial structure should be imposed to increase the participation of some Justices when their participation levels are a choice-particularly given that the conservative Justices already dominate the Court in terms of their numbers. The only alternative is that judicial participation is not a choice; that, somehow, the conservative Justices are less capable of participating, which is both unlikely-each of the Justices are highly qualified and none are shrinking violets-and ironic, as it relies on promoting a kind of affirmative action for the sake of conservative Justices, all of whom are

183 See, e.g., Jeff Nesbit, The Real Reason Clarence Thomas Rarely Speaks, U.S. NEWS (Mar. 30, 2016, 12:01 AM), www.usnews.com/news/articles/2016-03-30/why-clarence-thomas-rarely-speaksfrom-the-supreme-court-bench (relaying Justice Thomas's own explanation that he does not like to speak in public due to fear of discrimination, since he grew up speaking Gullah, and learned not to speak in public for fear that he would "be branded as poor, uneducated and disadvantaged," but also describing how others dispute this explanation).

184 Thomas: My Colleagues Ask Too Many Questions, CBS NEws (Apr. 6, 2012, 2:24 AM), https://www.cbsnews.com/news/thomas-my-colleagues-ask-too-many-questions (saying of questions during oral argument "I don't see where that advances anything ... I think that when somebody's talking, somebody ought to listen.") (reporting the Associated Press quoting Justice Thomas).

185 Id.

186 JOHN RAWLS, A THEORY OF JUSTICE 72 (2009) ("Social and economic inequalities are to be arranged so that they are ... to the greatest benefit of the least advantaged.").

${ }^{187} I d$. (describing his seminal theory of distributive justice, which also holds that "Each person is to have an equal right to the most extensive total system of equal basic liberties compatible with a similar system of liberty for all" and "offices and positions open to all under conditions of fair equality of opportunity."). 
generally opposed to such concepts. ${ }^{188}$ In other contexts, the conservative Justices are quick to decry attempts to equalize speech as "wholly foreign to the First Amendment."

Regardless of whether equalizing the opportunities of the Justices to participate is a worthy goal, the fact that in this new, ostensibly equal, format the conservative Justices are on average "more equal"190 than the liberal Justices sits uncomfortably with Roberts's claim to be a "neutral umpire."191

Others have noted that some of the differences between the telephonic cases and the in-person cases appeared to rest, in part, on gender differences. ${ }^{192}$ Most strikingly, nine of the eleven instances in which the Chief Justice interrupted a Justice, he interrupted a female Justice. Gender differences also arguably arose in terms of participation more generally, as Leah Litman and Jacobi note:

The three justices who were allowed to speak the most in the very politically salient cases - the two cases about the president and one about access to contraception under the Affordable Care Act-were conservative men ... The justices who received the three longest individual questioning periods were also all conservative men . . . By contrast, the justices who received the three shortest questioning periods that the chief justice ended were all liberal women. ${ }^{193}$

It is difficult to disentangle the effects of gender and ideology on the Court due to the fact that, during the period under study, all the female Justices were appointed by Democratic presidents and three of the four liberal Justices were female. It is no coincidence that the liberal camp has gender diversity and the conservative camp does not: Trump was the first Republican president since President Reagan to nominate a female Justice. We do not want to fault Chief Justice Roberts for any gender disparities that

188 See, e.g., Fisher v. Univ. of Tex. at Austin, 136 S. Ct. 2198, 2207 (2016) (Alito, J., dissenting, joined by Chief Justice Roberts and Justice Thomas) (arguing that the majority was wrong to not apply strict scrutiny to analyzing the constitutionality of considering race in university admissions); Fisher v. Univ. of Tex. at Austin, 570 U.S. 297 (2013) (7-1 opinion joined by all conservative Justices) (holding that race can be considered by universities in admissions only if such consideration can pass strict scrutiny).

189 Buckley v. Valeo, 424 U.S. 1, 48-49 (1976) (in relation to campaign finance laws aimed at equalizing speech, the majority said: "But the concept that government may restrict the speech of some elements of our society in order to enhance the relative voice of others is wholly foreign to the First Amendment."); see also Citizens United v. Fed. Election Comm'n, 558 US 310, 349-50 (2010) (quoting Buckley, 424 U.S. 1).

${ }_{190}$ In George Orwell's allegorical novel Animal Farm, it was proclaimed by the pigs who controlled the farm "All animals are equal, but some animals are more equal than others." GEORGE ORWELL, ANIMAL FARM 100 (1945).

${ }^{191}$ Roberts: 'My Job is to Call Balls and Strikes and Not to Pitch or Bat', supra note 17 ("The role of an umpire and a judge is critical. They make sure everybody plays by the rules. But it is a limited role. Nobody ever went to a ball game to see the umpire.").

${ }_{192}$ Litman, supra note 129 ("The Chief Justice only interrupted liberal Justices, and nine of the 11 interruptions were of women Justices"); Leah Litman \& Tonja Jacobi, Does John Roberts Need to Check His Own Biases?, N.Y. TIMEs (Jun. 2, 2020), https://www.nytimes.com/2020/06/02/opinion/johnroberts-supreme-court.html ("[O]n 11 occasions, the chief justice interrupted or cut off another justice. Every one of those 11 occasions involved justices who were appointed by Democratic presidents, and nine of the 11 involved female justices.").

${ }^{193}$ Litman \& Jacobi, supra note 192. 
may simply be a product of ideological differences, although he certainly does not seem to have heeded the call for greater sensitivity to gender differentials. ${ }^{194}$ When we turn to the question of interruptions and terminations of interchanges, a gender pattern becomes clear. ${ }^{195}$ But in our results so far, looking at the extent of participation in interchanges, we do not observe any gender effect-Justice Breyer is at least as disadvantaged by the change to the telephonic forum as are the female liberal Justices. As such, we conclude that most of the effect is ideological.

3. How These Changes Were Reflected in the Content of Oral Argument in the Telephonic Era

In addition to analyzing how the telephonic format changed the balance of participation in oral argument, we are also interested in how the new format changed how the Justices use their speaking time. Figure 5 does this by breaking down the content of the Justices' participation at oral argument by the rate of questions and non-questions (comments).

194 Jacobi \& Schweers, supra note 63, at 1484-85 (calling for the Chief to play a more active role in mitigating the gender difference they identify); Garrett Epps, Not Everyone Is Happy With the Supreme Court's Live Broadcasts, ATLANTIC (May 12, 2020), https:/www.theatlantic.com/ideas/archive/ 2020/05/lyle-denniston-despises-supreme-courts-new-format/611515 (quoting Lyle Denniston that in the telephonic cases, Roberts "was cutting people off not only in mid-sentence but also in mid-thought, both justices and counsel ... . It may be what I'm asking for is just a degree of humility from the chief justice.").

${ }_{195}$ See infra Part IV.D. 
Figure 5: Net change in content of participation: Differences in questions $\&$ non-questions ${ }^{196}$
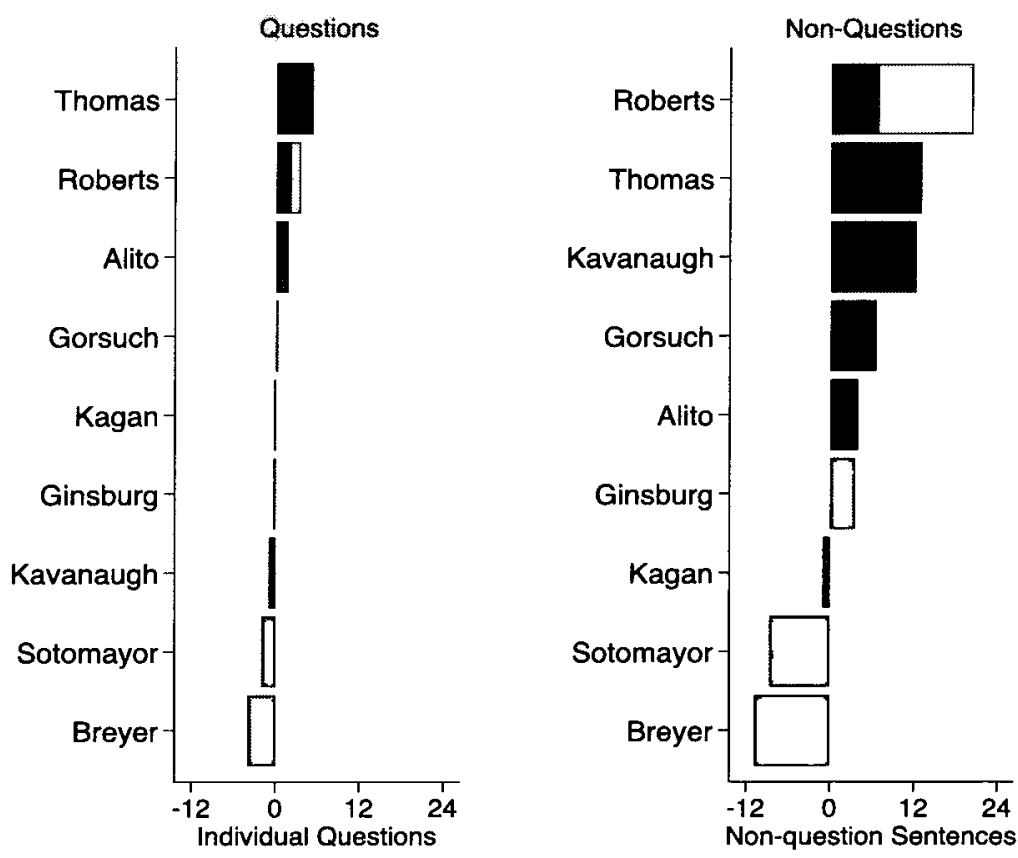

Here we utilize the same methodology as in Figure 4 (telephonic cases minus in-person 2019 cases) to analyze the nature of the Justices' participation in the different forums. ${ }^{197}$ We used an algorithm to classify each sentence spoken by the Justices as either a question or a comment. ${ }^{198}$ Using a similar method, Jacobi and Sag noted that "even while the Justices are talking more [in the modern era], they are not asking significantly more questions. Rather, they are posing... "non-questions"- that is, they are making statements and comments." 199 "They show that in the last quarter century, oral argument has increasingly become a vehicle for judicial advocacy, whereby Justices use their participation at oral argument to

\footnotetext{
${ }^{196}$ Note that there are often multiple questions and non-questions in a single speech event.

197 The questions number excludes when Chief Justice Roberts says, for example, "Justice Breyer?" to pass the baton to the next speaker in telephonic oral argument. It also excludes what we call the "Ferris Bueller moments" when a Justice or advocate is nonresponsive to being called upon - in such cases, we exclude both the words of the traffic management and the dead time as Chief Justice Roberts waits, sometimes hopelessly, for a response.

${ }^{198}$ Having studied the transcripts from hundreds of oral arguments, we are confident that the court reporters use question marks in an appropriate and consistent manner. We note, however, that our method will only count questions that are not cut short by an interruption. However, the number of interruptions is randomly distributed between questions and comments and a small enough proportion of speech episodes as to not dramatically affect the ratio of questions to comments.

${ }^{199}$ Jacobi \& Sag, supra note 46, at 1205.
} 
promote the side of the case that they ultimately vote in favor of, and to rebut the side of the case that they ultimately disfavor. ${ }^{200}$ One way the Justices do so is to direct questions to the side they ultimately vote for and to direct comments - often in the form of rebuttal - to the side they ultimately vote against. $^{201}$

It is apparent from the notable difference in size of the two graphs in Figure 5 that while to some extent conservative Justices used their additional time in the telephonic cases to ask more questions, they used considerably more of that extra time to engage in judicial advocacy through making comments. Although the number of questions asked by the conservative Justices increased, on average, by 1.6 , the conservative Justices' comments increased, on average, by 8.2 . In contrast, all of the liberal Justices registered fewer questions and made fewer comments - with the exception of Justice Ginsburg, who posed 4.6 more comments than she did previously. Note, however, that Justice Ginsburg's increase in comments was smaller than the increases of all of the conservative Justices. On average, questions by the liberal Justices declined by 1.6 per Justice per argument and their comments declined by 4.3 on average. The overall effect is that with considerably more opportunity to speak in the telephonic hearings, the conservative Justices used that time to engage in judicial advocacy by making additional comments rather than asking more questions. In contrast, the liberal Justices lost such opportunities to influence the arguments.

\section{Trends Within the Telephonic Cases}

In this Section, we shift from comparing the telephonic cases to the inperson cases to examining, in detail, variation within the telephonic cases. ${ }^{202}$ With only ten telephonic arguments, we are able to examine judicial activity case by case. In this way, we can see the overall impact of the inequality described above, for each ideological bloc, case by case. However, it should be noted that, unlike the previous two Sections, this Section is more open to interpretation as to whether the effect is unequal-we present arguments for and against a finding of inequality between the two ideological camps, case by case. But that does not undermine the quite dramatic discrepancies found in the previous two Sections when viewed at the individual Justice level.

As we compare telephonic cases, we divide the analysis between the petitioner and the respondent arguments (including amici in support for each side). We do this because it is well established that the Court treats petitioner and respondent differently in certain respects. For instance, petitioners win approximately two thirds of the time - an effect that has been explained by showing that the Justices "aggressively grant" cert to cases where they wish to overturn the decision below. ${ }^{203}$ In addition, the literature demonstrates that

${ }^{200} \mathrm{Id}$. at 1235 . See also Johnson et al., supra note 48 , at 258 (showing that Justices speak more words to the side they are more likely to vote against on the merits).

201 Jacobi \& Sag, supra note 46, at 1172.

202 In their early look at the telephonic cases, Litman and Jacobi argued that the unequal impact of the way that the Chief Justice ran oral argument in the telephonic cases is most apparent in politically salient cases. Litman \& Jacobi, supra note 192.

${ }^{203}$ Robert L. Boucher \& Jeffrey A. Segal, Supreme Court Justices as Strategic Decision Makers: Aggressive Grants and Defensive Denials on the Vinson Court, 57 J. POL. 824, 829 (1995) (finding that 
Justices treat petitioners and respondents differently, depending on whom they ultimately vote in favor of. ${ }^{204}$ With these points in mind, we turn to the analysis.

First, we examine the duration of each Justice's speaking time at oral argument using Justice-advocate pairs. Figures 6 and 7 show the results for petitioner's and respondent's time, respectively. The $x$-axes show the telephonic cases in the order in which they were heard. The y-axes show the duration of each argument, broken down by Justice. Note that Justice Kagan did not participate in the second case (USAID v. AOSI) and Justice Sotomayor did not participate in the final case (Colorado v. Baca).

every Vinson Court justice is significantly less likely to vote for certiorari if he eventually votes to affirm the lower court's decision). See also Charles M. Cameron, Jeffrey A. Segal \& Donald Songer, Strategic Auditing in a Political Hierarchy: An Information Model of the Supreme Court's Certiorari Decisions, 94 AM. POL. SCI. REV. 101, 113 (2000) (showing that conservative higher courts will review liberal lower courts but not conservative lower courts, and vice versa). In an era when the Justices only take between 70 and 80 cases per Term, this makes sense in terms of resource management; rather than using up one of their few slots to uphold a decision already made by a lower court the Justices focus on changing outcomes with which they disagree. For the sake of concision, when there is little difference between the Justices' behavior during towards the petitioner and respondent, we aggregate the analysis and show only the overall effect. However, we still report variation between how petitioner and respondent are treated in any oral argument.

${ }_{204}$ See, e.g., Black et al., supra note 53, at 578 (making clear that when Justices use harsher language towards one side they are less likely to vote in favor of that party). 
Figure 6: Justice time in individual telephonic cases: Petitioner's time, by pairs

Figure 7: Justice time in individual telephonic cases: Respondent's time, by pairs


Figures 6 and 7 show that there was enormous variance both between cases and within cases, in terms of the amount of time spent speaking to the petitioner and respondent within cases. Justice Alito was so active during the respondent's argument in Little Sisters that we had to use a different scale in Figure 7 to capture the more than sixteen minutes in which he spoke during the one side of that argument. This extraordinary dominance in this controversial case by Justice Alito actually drives the overall result that he dominated telephonic arguments. ${ }^{205}$ As we demonstrate below, however, the dominance of the conservative coalition in the telephonic cases is not the product of any single case.

Existing research shows that Justices systematically talk more during the time of the advocate whom they ultimately rule against. ${ }^{206}$ Little Sisters was a challenge to the Trump administration's expansion of the religious exception to the Affordable Care Act's requirement that group health insurance plans cover contraceptive services-without giving notice or soliciting public comment, the administration expanded the exemption to include a "moral" exemption. ${ }^{207}$ Given existing findings, it is perhaps

${ }^{205}$ If we exclude the Little Sisters argument and Chief Justice Robert's traffic management activity, Justice Alito comes in slightly behind Justice Sotomayor.

${ }^{206}$ Jacobi \& Sag, supra note 46, at 1227; Johnson et al., supra note 48, at 258.

207 Little Sisters of the Poor Saints Peter \& Paul Home v. Pennsylvania, 140 S. Ct. 2367, 2367 (2020). 
unsurprising that seventeen of the twenty-two minutes that Justice Alito spent talking in this case were directed to respondent, the side arguing in favor of the rights of women to have contraceptive coverage. Four and a half minutes into his lengthy dialogue with the advocate he would later vote against - and fourteen speech episodes, five questions, and thirty comments in-Justice Alito stated "If I could ask one other question." ${ }^{208}$ Chief Justice Roberts then permitted him just short of thirteen additional minutes of dialogue, including twelve more speech episodes, four questions, and twenty-one comments. $^{209}$

In contrast, when Justice Sotomayor questioned petitioner's advocatewhom she ultimately voted against - after two minutes and fourty seconds, two questions, and eleven comments, she appeared to be similarly asking for more time, but we can only infer this because the only words she was able to get out before she was interrupted by the Chief were "[o]ne last -.". 210 Once again the Chief treated Justice Sotomayor very differently, limiting her opportunity to speak and being far more generous with his conservative colleague. To be sure that comparing Justice Sotomayor's interaction with the petitioner's advocate to Justice Alito's interaction with the respondent's advocate is not misleading, we can instead compare Justice Sotomayor's and Justice Alito's treatment of respondent. Once again, the Chief's disparate treatment is evident. Justice Sotomayor was permitted four and a half minutes to Alito's more than sixteen minutes, six questions to his nine, and thirty-four comments to his fifty-one before being cut off by the Chief as she said "[s]o if --"." She was then permitted an additional thirty-two seconds of dialogue with the advocate before being cut off by the Chief again. ${ }^{212}$

It is not surprising that the ideological differences between Justice Alito and Justice Sotomayor would manifest in oral argument. Indeed, the general tendency of the Justices to speak more in disagreement than agreement in oral argument has been well established. ${ }^{213}$ Nor is it surprising that these differences would be on stark display in such a controversial case as Little Sisters. What is new, however, if not entirely surprising, is that we provide evidence that Chief Justice Roberts used his administrative role in an ideologically imbalanced manner. What our data demonstrates is that the format he selected and his control of oral argument in the telephonic hearings gave significantly more volume to conservative voices than liberal voices.

This is a strong claim to make, so to corroborate that the inequality created by the Chief during the telephonic cases is ideological, the next two figures explore that issue more deeply. Figure 8 examines the overall difference in the balance of time utilized by conservative Justices versus liberal Justices in the telephonic cases. ${ }^{214}$

208 Transcript of Oral Argument at 71, Little Sisters of the Poor Saints Peter \& Paul Home v. Pennsylvania, 140 S. Ct. 2367 (2020) (No. 19-431).

${ }_{209}$ Note that we distinguish between questions and comments at the sentence level and that a single speech episode will often contain multiple of each.

$210 \mathrm{Id}$. at 20.

${ }^{211}$ Id. at 79 .

$212 \mathrm{Id}$. at 80.

${ }^{213}$ See supra text accompanying note 200.

${ }^{214}$ In unreported figures that separate out the time of Respondent, the gap between the conservatives and liberals is even more extreme. 

pair

Figure 8: Balance of time between conservative and liberal Justices, by

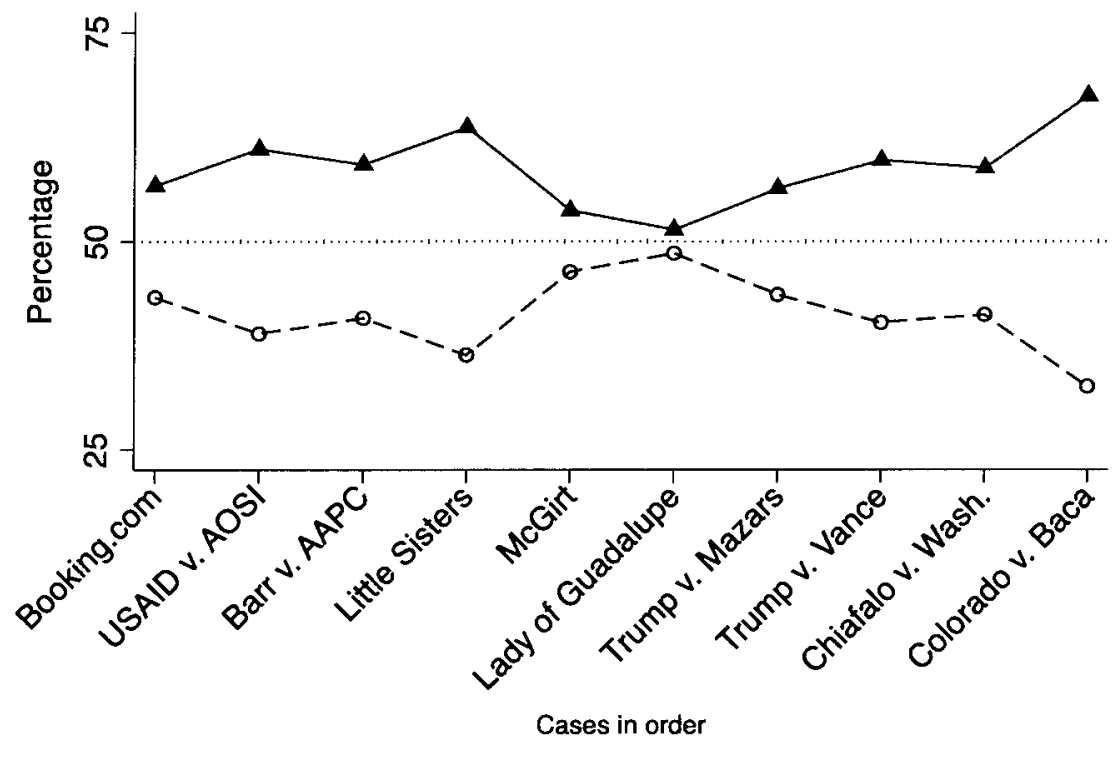

$\longrightarrow$ Conservative Justices $\quad--\theta--$ Liberal Justices

Justice Kagan did not participate in the USAID case

Justice Solomayor did not paticlapte in the Colorado case

Figure 8 shows the balance of time in each oral argument, divided between the conservative and liberal Justices, with the cases in order along the $\mathrm{x}$-axis and the percentage of time of each ideological camp on the $y$-axis. Note that, because the difference is measured in percentage of the argument, the two lines are a mirror image, centered on the $50 \%$ line. ${ }^{215}$

Here we observe that the overall dominance of the conservative Justices in the cases in aggregate above is not a product of a single, particularly salient case. Rather, the conservative Justices commanded a larger proportion of time in every single case of the ten telephonic cases, and significantly so in

${ }^{215}$ As noted in the figure, Justice Kagan did not participate in Agency for International Development and Justice Sotomayor did not participate in Baca. 
eight of the ten. ${ }^{216}$ Notably, this conservative dominance includes five cases directly affecting the 2020 presidential election. ${ }^{217}$

There is another way to analyze this question, which makes this last result appear less ideologically biased in favor of the conservative Justices. With five Justices nominated by Republican presidents and four Justices nominated by Democratic presidents during the time period examined here, the Court was not ideologically balanced. Normally, when analyzing oral arguments, this difference can be ignored because Justice Thomas rarely contributes. But with Justice Thomas choosing to participate in the telephonic oral arguments, arguably we should discount the time of the conservative Justices by normalizing for an ideologically balanced Court. Figure 9 does so, replicating Figure 8 by taking the average duration for the participating liberal Justices and the same for conservatives and converting it to a percentage. This normalizes the Court to a panel of equal numbers of liberals and conservatives and accounts for both the five-to-four imbalance on the then-Court and the recusals of Justice Kagan and Justice Sotomayor in $U S A I D$ v. $A O S I^{218}$ and Colorado $v$ Baca, ${ }^{219}$ respectively.

216 The two cases in which the conservative justices only slightly won out on the balance of time concemed jurisdiction over American tribe members for crimes committed within the historical tribe boundaries-McGirt v. Oklahoma, $140 \mathrm{~S}$. Ct. 2452, $2452(2020)$-and religious discrimination in employment-Our Lady of Guadalupe School v. Morrissey-Berru, 140 S. Ct. 2049, 2049 (2020). In the former, the Court ultimately ruled in favor of the liberal side of the argument, refusing to infer the abolishment of tribal sovereignty; in the latter, the Court ruled in favor of the liberal side of the argument, expanding the "ministerial exception" under the religion clauses of the First Amendment to proscribe adjudication of employment discrimination claims of teachers of non-religious subjects in Catholic schools, but it did so in a coalition of seven Justices that included two of the liberal Justices. As such, these two cases were seemingly less ideologically divided than many of the others.

217 Including consolidated cases. Trump v. Mazars U.S.A., LLP, 140 S. Ct. 2019, 2026 (2020) (assessing congressional subpoenas of the president), Trump v. Vance, $140 \mathrm{~S}$. Ct. 2412, 2420 (2020) (assessing the limits of state criminal investigations of the president), Chiafalo v. Washington, $140 \mathrm{~S}$. Ct. 2316,2320 (2020) (addressing the constitutionality of faithless electors), and Colo. Dep't of State v. Baca, 140 S. Ct. $2316(2020)$ (same).

${ }^{218}$ Agency for Int'l Dev. V. All. For Open Soc'y Int'1, Inc, 140 S. Ct. 2082, 2086 (2020).

${ }^{219} \mathrm{BaCa}, 140 \mathrm{~S}$. Ct. at 2316. 
Figure 9: Balance of time between conservative and liberal Justices, for a normalized Court, by pair

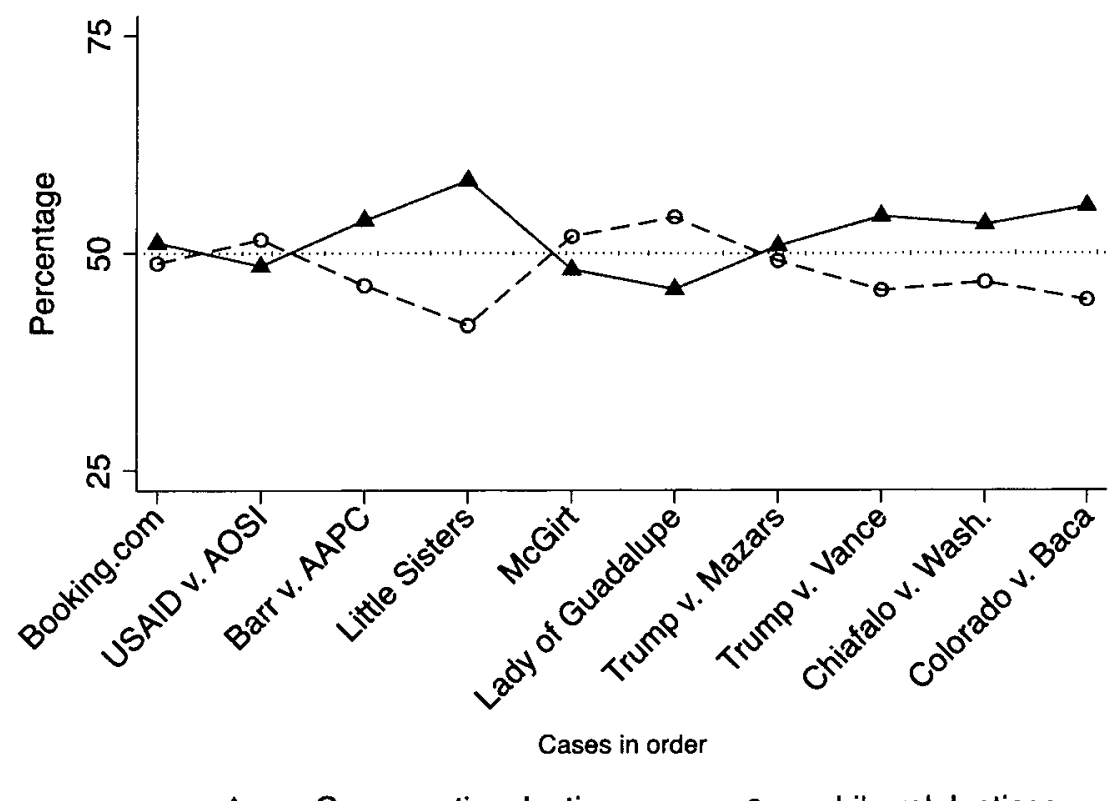

Normalized to a ideologically balanced Count

The results in Figure 9 look far more ideologically balanced than they do in Figure 8. The conservative Justices still dominate in cases such as Little Sisters, but speak less in Lady of Guadalupe, and have equal participation to the liberal Justices in four of the ten cases. ${ }^{22}$

So which figure best represents the true level of equality in the telephonic cases? The answer depends, once again, on how one views the purpose of oral argument. We must query: why is it that we care that some Justices are permitted more time than others? Obviously, it matters in terms of an intrinsic sense of fairness, but we are not concerned with the First Amendment rights of the individual Justices; rather, we are concerned with who and what the Justices represent, and whether what they represent gets fairly treated and equally heard.

The advocates represent each side of an issue but, ultimately, they represent their clients. This means advocates may sometimes undermine the interest of the overall class that the case represents in terms of the policy

${ }^{220}$ United States PTO v. Booking.com B.V., 140 S. Ct. 2298, 2301 (2020); Agency for Int'l Dev., 140 S. Ct. at 2086; McGirt, $140 \mathrm{~S}$. Ct. at 2452; Mazars, $140 \mathrm{~S}$. Ct. at 2026. 
issue, in order to achieve a specific outcome for the party in the case. ${ }^{221} \mathrm{We}$ know that Justices often act as advocates for one side or the other during oral argument, which raises concerns about judicial independence. But the advantage of judicial advocacy is that the Justices represent those positions without the same priority of the individual. Rather, they are focused on the policy outcome that affects both the individual and others more generally.

The ultimate purpose of oral argument is to give each side a fair hearing, and to make it clear that due process has been served in the form of a public hearing of the issue whereby both sides can make their claim, be heard, and be considered. ${ }^{222}$ Scholars have recognized the legitimacy-enhancing function of oral argument, with arguments acting as a signal to the parties and the broader public that the Court is performing its constitutionallymandated function by hearing and engaging in arguments from both sides. ${ }^{223}$ This goes beyond the disputes at hand: oral argument allows the public to see the Court as an impartial tribunal exploring issues of national importance through a balanced adjudicative process. ${ }^{224}$ Accordingly, it is appropriate to look at the time in which Justices of each ideological camp engage in dialogue with the advocates. As such, although it is sometimes appropriate to normalize such an analysis, ${ }^{225}$ it is not apt in this instance given the Chief Justice's role in shaping the time allocated to each Justice during the telephonic oral arguments.

As noted at the beginning of this Section, when comparing inequality at the ideological bloc level rather than at the individual Justice level, the results depend more on what the reader perceives is the ultimate goal of oral argument. This was not true of our analysis at the individual Justice level, which showed stark differences between how each Justice was treated in the May 2020 hearings. We believe that both sets of findings raise concerns about the legitimacy of the Court, as the ideological inequities revealed during telephonic oral argument risk harming the Court's very legitimacy as an institution engaged in due process and impartial adjudication.

${ }^{221}$ For instance, in Madison v. Alabama, 586 U.S. (2019), in arguing that the death penalty should not be applied to his client due to his brain damage that arose from a series of strokes, which left him unable to remember committing the crime that he was convicted of, the advocate for petitioner, Bryan A. Stevenson, went to great lengths to differentiate many other similar conditions to which his argument could otherwise apply, so as to make his argument seem less expansive. Transcript of Oral Argument, Madison v. Alabama, 586 U.S. (2019) (No. 17-7505).

${ }_{222}$ Sullivan \& Canty, supra note 34, at 1011 ; see discussion supra Part I.A.4.

${ }^{223}$ See, e.g., id. at 1025 ; Jacobi \& Sag, supra note 46, at 1168 (Oral argument is "the only opportunity for outsiders to directly witness the behavior of the justices of the highest court," and has an important role in the transparency of the Court itself). Justices have also made the same point. See, e.g., CHARLES E. WYZANSKI, JR., WHEREAS-A JUDGE'S PREMISES: ESSAYS IN JUDGMENT, ETHICS, AND THE LAW 61 (1965) (quoting Justice Brandeis as saying "The reason the public thinks so much of the . . . Supreme Court is that they are almost the only people in Washington who do their own work.").

${ }^{224}$ Sullivan \& Canty, supra note 34 , at 1012 .

${ }^{225}$ For example, Jacobi \& Schweers, supra note 63 , at 1462 , normalized by gender on the Court when looking at interruptions, since there has never been close to a majority of women on the Court. But that is differentiable because there is no theory that we know of that suggests that men and women ought to be equally interrupted in aggregate as representative camps, making it appropriate to interrupt the female Justices on the current Court three times as often as the male Justices, and thus inappropriate to normalize, as here. 


\section{THE ABRUPTNESS OF THE TERMINATION}

Our final inquiry concerns how interchanges between Justices and advocates end. We ask: Does the Justice choose to end the interchange? Or does the Chief Justice intervene to end the interchange? Are there patterns as to when the Chief Justice intervenes and when he does not? And do these patterns follow the same ideological lines as the previous results? It may be the case that the Chief Justice needs to end many interchanges to keep the arguments from going even longer in the telephonic cases, but it is hard to justify this practice if it is handled inequitably. The analyses that follow most directly allow us to assess the extent to which the Chief Justice's actions shaped Justices' participation.

In the next three figures, we compare terminations of interchanges in 2018 and 2019 in-person cases to terminations in telephonic cases. We differentiate between three different possible endings to an interchange. First, a Justice can be "cut off," or interrupted by another Justice. ${ }^{226}$ In the telephonic cases, those cutoffs are only done by the Chief Justice. Second, an advocate can be cut off. ${ }^{227}$ In the telephonic cases, once again this is done by the Chief Justice, since the other Justices do not jump in to speak out of order. Note that the Justice involved in the interchange often interrupts an advocate, but that interruption does not constitute a cut off because an interchange is an ongoing back-and-forth between two participants; this may include multiple interruptions as long as a third party does not become involved, at which point the interchange ends and another begins. In the inperson cases, there is more variation. Typically, another Justice interrupts the interchange between the advocate and the Justice, but in the rarer case of an interchange between two Justices, an advocate or the Chief could step in, ending the intra-Justice interchange. Third, and finally, an interchange can end in a "take over," when the next Justice begins speaking-that is, there is no interruption. Once again, in the in-person cases, any individual can take over the dialogue after another has spoken. In the telephonic cases, that next Justice is always the Chief Justice, who introduces the following Justice. The difference between the Chief Justice taking over versus cutting off is whether he does so via an interruption. ${ }^{228}$ There were seventy-four instances (approximately $30 \%$ of the total) where these takeovers involved a voluntary passing of the baton, often by saying, "Thank you." 229 Others involved the

${ }^{226}$ An interruption by the advocate does not terminate a Justice-advocate interchange, it is simply part of it. In theory, the advocates should "[n]ever interrupt a Justice." CLERK OF THE CT., supra note 79, at 9. Nonetheless, advocate interruptions are common. See Jacobi \& Schweers, supra note 63, at 1437 (finding 7,239 interruptions of Justices between 2004 and 2015 - note that this number includes Justiceto-Justice interruptions, but that is a small minority of occurrences).

227 Remember that both figures show pair behavior, not simply individual behavior, and thus incorporate the participation of the advocate with whom each Justice is engaged.

${ }^{228}$ Note that Litman explores a similar concept, but her definition may be slightly more subjective than ours. She defines an interruption in the telephonic hearings as when "the Chief Justice interrupted another Justice's remarks or ended their questioning period before an advocate had a chance to respond to the question." Litman, supra note 129 , at 23 . Judgments as to whether an advocate "had a chance to respond to the question" need to be formalized before they can be applied by algorithms to large datasets.

${ }^{229}$ Our count of seventy-four does not include instances where the Chief ended the argument session with a "thank you" or where the Chief interrupted an associate justice to ask if he or she had anything else to ask and the associate responded by saying "no" and then thanking the Chief. 
Chief unilaterally indicating that a Justice's term has ended without interruption.

First, we analyze the in-person cases to determine how interchanges normally terminate. Figure 10 shows the 2019 in-person cases and Figure 11 shows the 2018 in-person cases. The two figures display the number of occurrences of any given termination on the x-axes and the three categories of termination on the y-axes. It shows there is variation among the Justices; we can see at a glance how involved each Justice is at oral argument. ${ }^{230}$

Figure 10: Pair terminations in 2019 in-person oral arguments
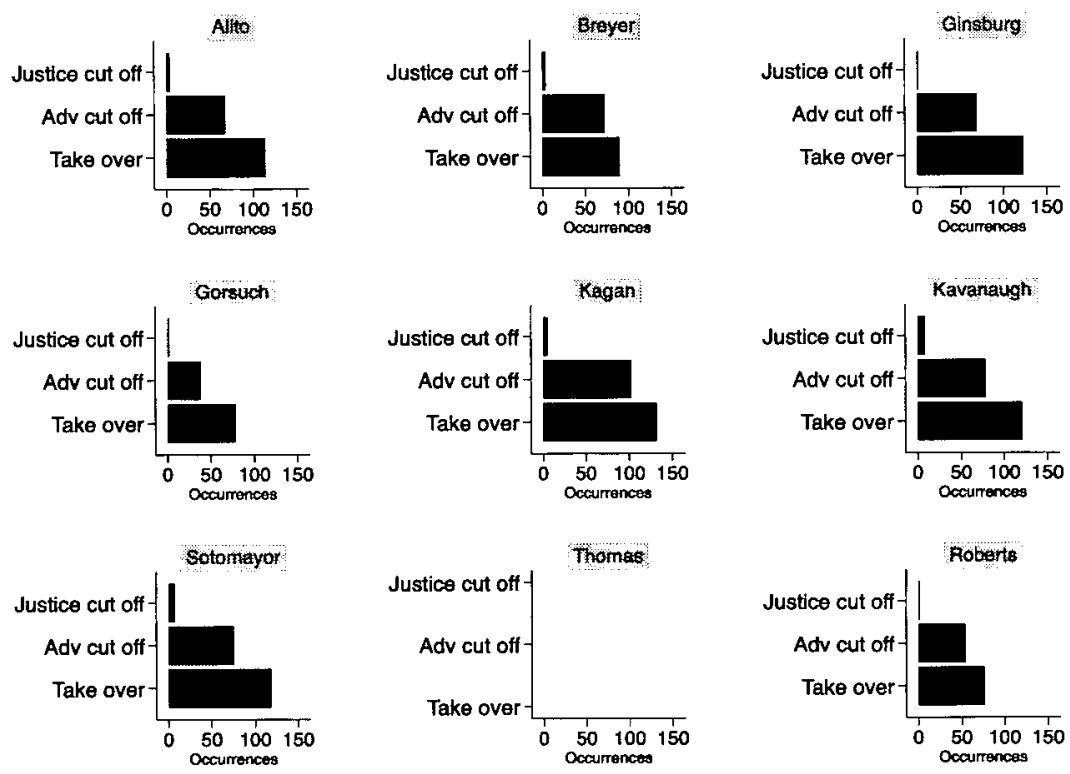

${ }^{230}$ Obviously, Justice Thomas barely registers but it is also apparent that Justice Gorsuch and Chief Justice Roberts are less active in dialogue with advocates than are the other Justices. In 2018, Justice Sotomayor was the most active, with 338 interchanges terminated, followed by Justice Kagan, at 327 . In the 2019 in-person cases, Justice Kagan is the most active, with 239 interchanges/terminations, followed by Justice Kavanaugh with 208 , and Justice Sotomayor with 201. Justices Ginsburg and Alito are also relatively active, at 193 and 186 , respectively. Justice Gorsuch is the least active at 118 , other than Justice Thomas. Note that the lower numbers of interchanges terminated in the 2019 in-person cases reflect the lower number of in-person cases that were heard in 2018 . 
Figure 11: Pair terminations in 2018 in-person oral arguments


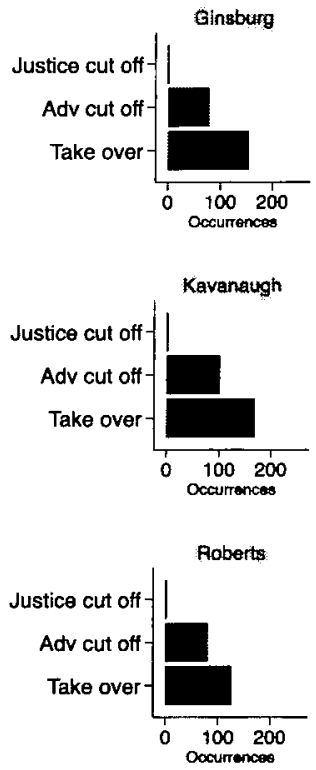

When we look at the different types of interchange terminations in the in-person cases, while each Justice is interrupted occasionally, there are no striking inequalities. There are differences-Justices Kavanaugh and Sotomayor are interrupted the most, with eight and seven cutoffs, respectively, in the 2019 in-person cases; in the 2018 cases, Justice Sotomayor is cut off the most, with a very high thirteen cutoffs, followed by Justice Kagan with five, followed by Justices Alito and Breyer, with four each. Even though Justice Sotomayor is seemingly treated differently than the other Justices, with as many cutoffs as the next three highest Justices combined, each of these numbers must be put in the context of occurring in a Term in which each of these Justices were involved in hundreds of interchanges being terminated. Every Justice had the majority of their interactions terminated by a take over rather than by a cutoff. If we look at the proportion of terminations ending in a take over, the range in 2019 was 0.54 for Justice Breyer to 0.64 for Justice Ginsburg; the range in 2018 was 0.60 for Chief Justice Roberts followed by Justice Sotomayor at 0.67 (excluding Justice Thomas, who was at 1.00 , but he only had one interchange, which happened to end in a take over).

Even though Justice Sotomayor seems to be treated with less respect than her colleagues in some ways, ${ }^{231}$ importantly, there is no obvious ideological

231 On the relationship between politeness and interruptions, as well as other forms of politeness identified at oral argument, see Jacobi \& Schweers, supra note 63, at 1442; Tonja Jacobi \& Matthew Sag, 
division, and no indicia that the female Justices are being treated differently as a group. Unfortunately, the same cannot be said of the telephonic cases. Figure 12 shows the divergence, applying the same analysis to the telephonic cases.

Figure 12: Pair terminations in telephonic oral arguments
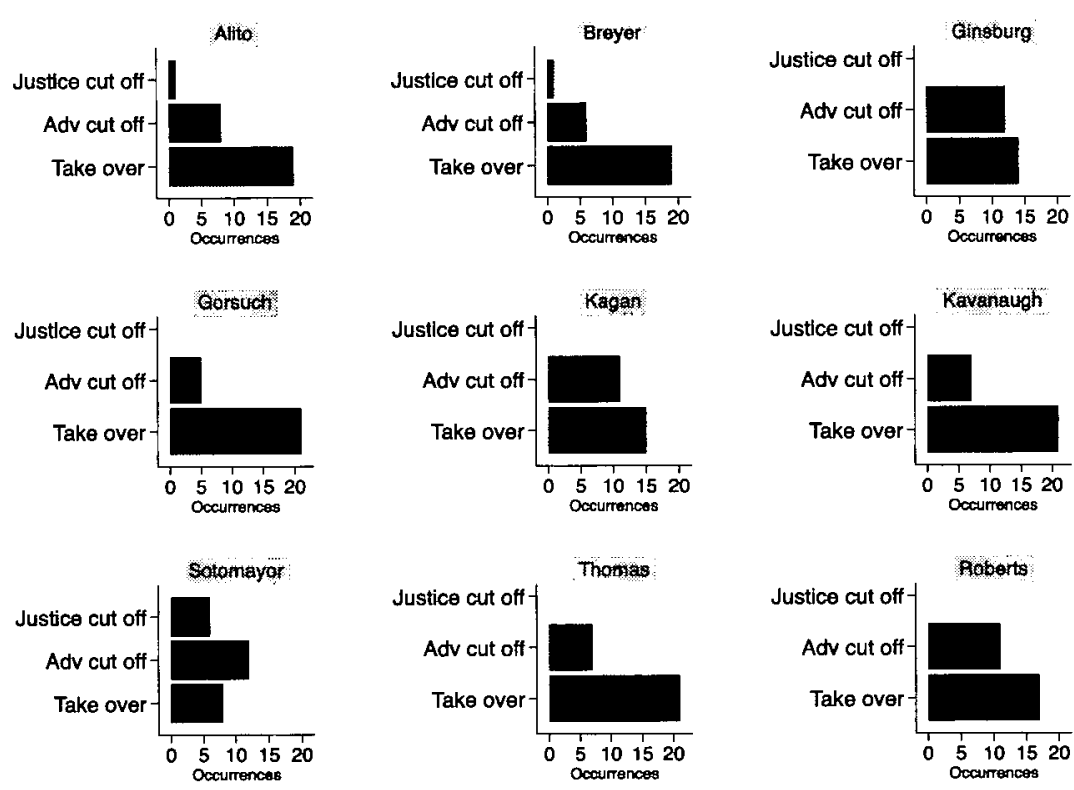

The results are quite different in Figure 12 than they were in Figures 10 and 11. Specifically, it shows a much higher level of variation in the Chief Justice deciding whether a Justice is permitted to continue their dialogue with the advocate.

Terminating a Justice's dialogue by interrupting them may strike some as an issue of politeness and decorum, but the real question that the manner of termination informs is how much latitude the Chief Justice accords to different Justices. The more a Justice's dialogue is cut short by an interruption, the less deference or consideration their views would appear to warrant. This is more than symbolic: being cut off directly stops a Justice from continuing his or her dialogue with an advocate. Thus, Figure 12 illustrates an important facet of the differences in the latitude the Chief accorded each of the Associate Justices - and indeed, himself. A brief glance at the data shows that each of the bottom bars, representing take overs, is the largest of the three categories for all of the Justices except one: Justice Sotomayor. Also of note is that the other two Justices whose bottom bars are even close to any other bar are the two other female (and liberal) Justices, Justice Ginsburg and Justice Kagan. To be fair, these figures do not show the

Politeness and Formality in Supreme Court Oral Argument, SCOTUS OA (Aug 27, 2018), https://scotusoa.com/politeness-and-formality. 
context in which a Justice's interchanges were terminated. The figures also do not show the number of times the speaker voluntarily terminated an interchange. However, the figures do suggest that the Chief used his authority to end Justices' dialogue with attorneys unevenly. It is worth exploring this in greater detail.

In the telephonic cases, Justice Sotomayor was cut off by the Chief in six of the twenty-six terminations to her interchanges-or $23 \%$ of the time. In the entirety of the telephonic cases, only two other Justices had any of their interchanges with the advocates terminated by the Chief-Justices Breyer and Alito. Each occurred only once. The Chief interrupted Justice Sotomayor three times as often as he interrupted all of the other Justices combined in the telephonic hearings. Jacobi and Schweers showed that male Justices interrupt female Justices disproportionately often and that Justice Sotomayor is consistently the most interrupted Justice by both advocates and other Justices. ${ }^{232}$ Figure 12 suggests that the seemingly rigid formal structure of the telephonic cases did not alleviate this trend-telephonic cases simply gave the Chief Justice more control over the flow of conversation.

Further, even more of Justice Sotomayor's dialogues with advocates ended with the Chief intervening. In addition to the six terminations when the Chief directly interrupted Justice Sotomayor midsentence, the Chief also interrupted the advocate while in dialogue with Justice Sotomayor twelve times, representing $46 \%$ of her interchanges. Only eight, or $31 \%$, of Sotomayor's interchanges ended in take overs. This was not because Justice Sotomayor's interchanges with the attorneys were longer than other Justice's interchanges, as shown above in Figures 4, 6, and 7. Thus, Chief Justice Roberts actively intervened to cut short discussion between Justice Sotomayor and an advocate $69 \%$ of the time she was engaged in any dialogue with an advocate.

Justices Ginsburg and Kagan were not themselves interrupted by the Chief, but almost half of their interchanges with advocates involved the advocate being cut off while answering one of their questions-twelve out of twenty-six (46\%) for Justice Ginsburg and eleven out of twenty-six (42\%) for Justice Kagan. As such, the other two female Justices' participation at oral argument was stymied even when they were not directly interrupted.

The treatment of the male Justices stands in direct contrast. Despite being the most active Justice in the telephonic cases, Justice Alito was interrupted by the Chief far less often than the Chief interrupted any of the female Justices: Justice Alito had well under one-third of his interchanges with the advocates end in a cutoff of the advocate-eight out of twenty-eight $(29 \%)$. Similarly, Justices Kavanaugh and Thomas each had only one-quarter of their interchanges end in a cutoff - seven out of twenty-eight each (25\%); and Justice Gorsuch had even less, with fewer than one-fifth of his interchanges ending in the Chief cutting off his dialogue with the advocatefive out of twenty-six (19\%).

232 Jacobi \& Schweers, supra note 63 , at 1437, 1468, 1470. 
In every measure other than terminations, Justice Breyer was the "biggest loser" in the telephonic cases and was clearly in the liberal camp. ${ }^{233}$ But in this one respect, the end of Justice Breyer's interchanges did not look like that of the female liberal Justices, but like the male conservative Justices' interchanges. This suggests that the gender effect in interruptions at oral argument that Jacobi and Schweers identified is alive and well, despite calls on the Chief to improve the gender balance on the Court, ${ }^{234}$ and that initial observers were correct that gender was at play in the diversity of the Chief's treatment of the other Justices in the telephonic cases ${ }^{235}$ - at least with respect to interruptions. Note that Justice Breyer voluntarily ended many of his telephonic interchanges and was more succinct than usual. However, while it is possible that the male Justices were more likely to voluntarily cede their time, the data indicate that the female Justices frequently wanted to continue an interchange and were constrained by the Chief Justice.

Our final indicia of the Chief's selectivity in running the telephonic oral arguments is in the duration of the terminal speech episode, or final spoken portion, in an interchange. We want to know how an interchange ends-in a cutoff or a take over-and the substantiality of the last remark when not interrupted. This is important because even when a speaker is not technically interrupted, they might be effectively disrupted. For instance, if a Justice asks an advocate if they have an answer to a complicated question, the advocate might begin by responding, "Yes, Your Honor." We would then expect the advocate to extrapolate, but if another participant begins speaking before the advocate has a chance to reply with substance, the advocate may as well have been interrupted. The justice may have asked a question or made a comment but not received a substantive response from the advocate. By measuring the duration of the last remark, we can better understand substantive intrusion on dialogue.

\footnotetext{
233 See supra Figures 4 and 5 and associated text.

234 Jacobi \& Schweers, supra note 63 at 1484-85.

${ }_{235}$ Litman, supra note 129; Litman \& Jacobi, supra note 192.
} 
Figure 13: Duration of terminal speech episode in interchanges, by pair


Shorerer durations are more aburup terminations
Jusisicic Thom

Figure 13 shows the duration of each Justice's terminal speech episode in an interchange. ${ }^{236}$ Specifically, it shows an average for the telephonic cases, the 2019 in-person cases, and the 2018 in-person cases, from left to right. Note that Justice Thomas does not appear in the middle graph as he did not speak in the 2019 in-person cases.

Once again, we see a change in the duration of terminal speech episodes from the in-person cases to the telephonic cases. In in-person cases, the liberal Justices included more substance in their terminal speech episodes than in telephonic cases. In fact, in the in-person cases, the liberal Justices excelled at this tactic over the conservative Justices: the ideological ordering is only disrupted by the appearance of Chief Justice Roberts in the top half of the graph in 2019 and Justice Kavanaugh in 2018. In contrast, in the telephonic cases, the liberal Justices are more likely to be in the bottom half of the rankings. The one exception is Justice Ginsburg. She went from ranking first in getting substantive answers to her final question to fourth in the telephonic cases. In telephonic cases, she sits behind Justice Alito and Justice Thomas, who once again benefit most from the switch to the telephonic format, with Justice Gorsuch and the Chief himself close behind.

Justice Kavanaugh also appears near the bottom of the telephonic cases in duration of final speech episode, but this was also true in the 2019 inperson cases, albeit less-so in the 2018 cases. That is, Justice Kavanaugh was never particularly adept at ensuring that his final questions were substantively addressed. The liberal Justices, in contrast, played the game of in-person oral arguments well. However, this did not translate to telephonic cases, where much depends on Chief Justice Roberts choosing which Justice will have their questions answered substantively.

${ }^{236}$ Not including the traffic management interchanges of the Chief Justice. 
By averaging the duration of terminal speech episodes of each Justice in the 2018 and 2019 in-person cases, and comparing them to the telephonic cases, each of the liberal Justices dropped between 1.5 to 3.5 rankings of duration. Once again, Justice Sotomayor is the Justice most disadvantaged by the Chief's selective approach in the telephonic cases, followed by Justice Ginsburg, and then Justices Kagan and Breyer. In contrast, Justices Alito, Gorsuch, Thomas and Chief Justice Roberts all benefited; only Justice Kavanaugh among the conservatives lost ground-but only one spot on average.

So, not only are the liberal Justices cut off more, as we saw above, but, for whatever reason, their interchanges with the advocates ended more abruptly than those of the conservative Justices. ${ }^{237}$ And once again, the liberal women in particular are most disadvantaged. Liberal female Justices may also be treated less politely-shorter durations could indicate more abrupt endings to final speech episodes. The length of an interchange indicates the substance of the Justice's dialogue with the advocate; the length of the final speech episode in the interchange is in many ways about courtesy-it shows who is given leeway and deference to get their questions answered in any substantial sense. But the disruption has a substantive effect, limiting the capacity of the Justice to continue their dialogue with the advocate. By using his additional power under the telephonic forum structure, Chief Justice Roberts's actions promoted the ability of Justices Thomas and Alito to participate, and mitigated the influence of Justices Sotomayor, Ginsburg, Kagan, and Breyer. As such, the appearance of equality given by the left panel of Figure 2, which displays pairs' interchanges in the telephonic cases, does not fully hold up.

Our analysis illustrates the difference between formal equalitycaptured by the number of interchanges - and substantive equality - as measured in a variety of ways, from duration to interruptions to more than tokenistic opportunities for advocates to answer a Justice's question. All but the most superficial tests of equality have shown that the discretion allocated to the Chief Justice during the telephonic oral arguments led to disparate treatment for the Justices and groups of Justices. Chief Justice Roberts did not apply a uniform standard across Justices. This lack of uniformity repeatedly benefited the conservative Justices, except in regards to interruptions, where the male Justices benefited. As such, Chief Justice Roberts was, to some extent, playing Calvinball in the telephonic cases, making up the rules as he went along. But in some ways this understates the problem: Chief Justice Roberts was not even following the spirit of that rather quixotic enterprise, Calvinball, by varying his behavior randomly; instead, he was consistently benefiting his friends and allies.

${ }^{237}$ We could review the transcript and make a judgement about whether the advocate had managed to fully answer the relevant question, but this subjective approach does not scale if we are interested in comparing telephonic to in-person oral argument. 


\section{CONCLUSION}

The shift to telephonic oral arguments was highly revealing of the institutional dynamics of the Supreme Court and of John Roberts as Chief Justice. While it is indisputable that some remote argument forum was essential to permit the Court to continue to carry out its duties during the COVID-19 crisis, the specific forum chosen was a poor substitute for inperson oral argument. Telephonic oral argument was less dynamic, needlessly hierarchical, and, although it promised a veneer of equality between the Justices, it functioned and was administered with a clear tilt in favor of the conservative wing of the Court and, in some respects, in favor of the male Justices over the female Justices. The rigid structure of the telephonic cases obscured considerable discretion for Chief Justice Roberts and provided him a mask of neutrality.

And yet, once the Court heard the last of the oral arguments, the headlines that followed focused on key cases in which the Chief Justice ostensibly gave big wins to liberal causes. ${ }^{238}$ Most notably, in Russo v. June Medical Services, the Chief joined the liberal Justices to strike down as unconstitutional Louisiana's Unsafe Abortion Protection Act that required doctors who perform abortions to have admitting privileges at a nearby hospital. ${ }^{239}$ Yet, the Chief also gave big wins to conservatives in other cases, including all three religious freedom challenges, including permitting the administration to undermine women's access to contraception by once again favoring religious freedom over bodily autonomy. ${ }^{240}$ But this does not make Chief Justice Roberts a moderate, giving wins to each side; rather, even where he voted for liberal outcomes, he did so in a highly conservative manner. For instance, in June Medical, he wrote separately to "cabin[] the plurality[,] ... find common ground with the dissenters, including disdain for the Supreme Court's most recent precedent[,] [and] argue[] for a return to a system that left people seeking abortion without access to the care they need. In his concurrence, Roberts plants a flag to mark the battlegrounds for future abortion fights." ${ }^{241}$ Chief Justice Roberts's goal in this case and others

${ }^{238}$ See, e.g., Robert Costa, Trump Supporters Hope to Use Conservative Anger at Chief Justice Roberts to Energize Troubled Campaign, WASH. POST (July 1, 2020), https://www.washingtonpost.com/politics/trump-john-roberts-abortion-supreme-

court/2020/06/30/34513f92-bae8-1 lea-80b9-40ece9a701dc_story.html ("In a remarkable stretch of decisions over the past two weeks, Roberts has infuriated conservatives and the Trump administration by finding that federal anti-discrimination law protects gay, bisexual and transgender workers and stopping the president from ending the federal program that protects undocumented immigrants brought into the country as children.").

${ }^{239}$ June Med. Servs. L. L. C. v. Russo, 591 U.S. (2020).

240 Little Sisters of the Poor Saints Peter \& Paul Home v. Pennsylvania, 140 S. Ct. 2367, 2372 (2020) 2372; Our Lady of Guadalupe Sch. v. Morrissey-Berru, 140 S. Ct. 2049, 2049 (2020).

${ }^{24}$ Gretchen Borchelt, June Medical Services v. Russo: When a "Win" is Not a Win, SCOTUSBLoG (Jun. 30, 2020, 12:31 PM), https://www.scotusblog.com/2020/06/symposium-june-medical-services-vrusso-when-a-win-is-not-a-win; see also Justice John Roberts Joins the Supreme Court's Liberal Wing in Some Key Rulings, ECONOMIST (Jul. 2, 2020), https://www.economist.com/united-states/ 2020/07/02/justice-john-roberts-joins-the-supreme-courts-liberal-wing-in-some-key-rulings (arguing that, in June Medical, "with an eye on future cases, the chief justice proceeded to undercut the very precedent he had relied upon to reject Louisiana's law," and more generally "[h]e is cultivating a reputation for non-partisanship at the Supreme Court while advancing primarily conservative goals."). But see, e.g., Jeffrey Rosen, John Roberts is Just Who the Supreme Court Needed, ATLANTIC (Jul. 13, 
is about pursuing a conservative agenda within the confines of protecting the legitimacy of the Court at a time when critics are talking about Supreme Court expansion, ${ }^{242}$ and he was seen as greatly benefiting from, and interested in protecting, the Trump administration. ${ }^{243}$

Our analysis shows how misleading it would be to conclude from recent cases that Chief Justice Roberts does not have a keen interest in promoting a conservative agenda for the Supreme Court. The telephonic forum was the perfect metaphor for John Roberts's approach to being Chief: have the appearance of neutrality, with each Justice getting the same number of turns at oral argument, in an order determined exogenously by the history of the order of appointments to the Court; but in reality, subtly and strategically promote the interests of the dominant groups that he representsconservatives and men. ${ }^{244}$ Chief Justice Roberts is simply farsighted and strategic enough to alter policy while maintaining plausible deniability of the criticism that he believes: "stare decisis is for suckers."245

Given that Supreme Court Justices have overwhelmingly been shown to be ideological, ${ }^{246}$ perhaps it is unrealistic to expect any Chief Justice not to behave accordingly. But the Court had a choice in which institutional mechanism to select as an alternative to in-person oral argument. It could have chosen a videoconferencing platform such as Zoom, which would have permitted the Justices to virtually "raise their hands" when they had a question. ${ }^{247}$ That would have made the arguments much more like in-person

2020), https://www.theatlantic.com/ideas/archive/2020/07/john-roberts-just-who-supreme-court-needed/ 614053 (lauding Roberts for "decisively and impressively" achieving the goal of bipartisan decisionmaking, "guided by law rather than politics," and siding with the liberals in the abortion case in order to protect stare decisis and the legitimacy of the Court).

242 See, e.g., Holly Otterbein, Liberal Groups Back Plan to Expand Supreme Court, PoLITICO (June 11 , 2020), https://www.politico.com/news/2020/06/11/liberal-groups-expand-supreme-court-plan313037 (reporting that 350 progressive organizations have backed a plan to expand the Supreme Court in order to weaken the conservative majority and to counter the "aggressive tactics" of the Republicans in refusing to seat Merrick Garland and changing the filibuster rule).

${ }_{243}$ See, e.g., Adam Serwer, The Roberts Court Completes Trump's Cover-Up, ATLANTIC (July 10, 2020), https://www.theatlantic.com/ideas/archive/2020/07/the-roberts-court-has-completed-trumpscover-up/614023/ ("[I]t is Roberts who is playing games, shielding Trump from accountability and gilding the Court's image, asserting a bravery and independence that it has not actually displayed."). But see Robert Barnes, John Roberts's Supreme Court Power Hinges on Trump's Reelection. But Not in the Way You Might Think, WASH. POST (July 17, 2020), https://www.washingtonpost.com/news/ powerpost/paloma/daily-202/2020/07/17/daily-202-john-roberts-s-supreme-court-power-hinges-ontrump-s-reelection-but-not-in-the-way-you-might-think/5f10c22f602ff1080719ddad (arguing that Roberts's power comes from being in the center, rather than from being the Chief, and agreeing that Roberts benefited from Trump's election in 2016, arguing this aspect of his power would actually decrease if Trump was reelected in 2020).

244 Oral argument is not the only way in which Chief Justice Roberts is said to have strategically manipulated the Court's process, particularly since the pandemic: an inside source reports he has "exerted unprecedented control over cases and the court's internal operations, especially after the nine were forced to work in isolation because of Covid-19." Biskupic, supra note 6 (reporting that Roberts "maneuvered on controversial cases in the justices' private sessions" and other strategic activity to enhance his power at the Court).

${ }_{245}$ See Strict Scrutiny Podcast, Stare Decisis Is for Suckers, https://strict-scrutiny-podcastshop.myshopify.com/collections/stare-decisis-is-for-suckers (last visited May 5, 2021) (with particular attention to the section of the Strict Scrutiny podcast's store devoted to this satirical theme).

246 See supra note 13.

247 As one of us suggested. Coyle, supra note 4 (quoting Tonja Jacobi); Mark Walsh, What Will Change When SCOTUS Hears Oral Arguments by Phone?, A.B.A.J. (Apr. 21, 2020), https://www.abajournal.com/web/article/supreme-court-agrees-to-hear-oral-arguments-by-telephonenext-month-attomeys-ponder-what-to-wear (quoting Tonja Jacobi, "I would have thought it would be more natural for the justices to use a program like Zoom, but it didn't surprise me they opted for something more basic ... . The court has always been reluctant to have any sort of video argument."). 
hearings, with Justices asking questions and making comments when issues arose, rather than in the artificial order of seniority. Such a system would have also provided a mechanism for ensuring that the Justices spoke in order of who "got in line" first, rather than who spoke over whom ${ }^{248}$ or who is favored by the Chief Justice. In contrast, the telephonic argument format employed by the Court was prone to enabling inequality by the moderator, deliberate or otherwise.

As noted, other courts utilized videoconferencing. ${ }^{249}$ The North Carolina Court of Appeals is using WebEx, a more secure version of the commonly used Zoom technology. ${ }^{250}$ Judge Lucy Inman ${ }^{251}$ reports that the change to videoconferencing went smoothly for that court and that technologies such as WebEx have advantages over a non-video-based technology; for instance, the advocates and the judges are able to see one another's facial expressions which improves flow and reduces interruptions. ${ }^{252}$ The N.C. Court of Appeals determined that the best way to continue enabling the judges to jump in to the dialogue when desired was to physically raise their hands over video to indicate a question. This avoids conversational disruptions in a non-inperson forum, such as when there are delays between the video and audio, or if a party forgets to unmute the microphone. ${ }^{253}$

The N.C. Court of Appeals does not have the same aversion as the U.S. Supreme Court to cameras in the Court: it was planning on introducing live streaming of oral arguments prior to the COVID-19 pandemic, which simply sped up implementation of such technology. ${ }^{254}$ But the N.C. Court of Appeals also does not have the same public profile as the Supreme Court and so, presumably, does not have the same level of public interest in its oral arguments. Despite that, approximately 100 people virtually attended the first case conducted on WebEx, even though the case was not especially high-profile; for some subsequent cases, the virtual audience has been multiples of that number. ${ }^{255}$ This may suggest that the public has a high level of interest in the conduct of court proceedings; given that the dominant website that provides access to Supreme Court oral argument recordings and transcripts, Oyez, has over a seven million unique users in a year, ${ }^{256}$ no doubt

${ }^{248}$ Which Jacobi \& Schweers show to also be highly gendered. Jacobi \& Schweers, supra note 63, at 1461 (showing that not only are male Justices more likely to interrupt female Justices than fellow male Justices, but male Justices are less likely to recognize when they have interrupted a female Justice rather than a male Justice, and significantly more likely to hand the floor to the male Justice they have interrupted).

${ }^{249}$ See supra note 4.

250 See e g. Rebekah Carter, Cisco Webex vs. Zoom: Choosing the Right Team Tech, UC TODAY (Apr. 22, 2020), https://www.uctoday.com/collaboration/video-conferencing/cisco-webex-vs-zoomcomparison ("Both Cisco and Zoom are heavily focused on security, although both companies have had their issues with privacy and protection in the past . . . . However, Webex is more likely to be the top choice for enterprises and large companies that host a lot of meetings with Cisco hardware.").

251 Judge Inman served on the North Carolina Special Superior Court Judge, 2010 2014, before joining the North Carolina Court of Appeals in 2014; she is currently a candidate for the North Carolina Supreme Court.

252 Telephone discussion between Tonja Jacobi and Judge Lucy Inman (July 23, 2020, 11:15 AM). Notes available from the authors.

${ }^{253}$ Id.

${ }^{254}$ Id.

255 Id.

256 Jacobi \& Sag, supra note 84. 
the public would also be actively interested in televised Supreme Court argument. It is equally likely that the Supreme Court continues to resist such a move, though note that it also resisted making audio recordings promptly available until public interest in hearing argument in Bush v. Palm Beach County Canvassing Board and Bush v. Gore grew too great for the Court resist. ${ }^{257}$

The Court does not need to make this difficult choice-the option to adopt videoconferencing for oral arguments does not need to equate to cameras in the courtroom in the sense that the Supreme Court Justices fear. The Supreme Court could use videoconferencing without making the video part of the general broadcast; the Justices and advocates could have access to video to promote a more dynamic, interactive oral argument, while only making the audio available to the public. This would retain all of the advantages of interactive arguments, akin to in-person arguments, without upsetting those who want to keep the Court's proceedings somewhat under wraps. While such a format would not provide a dedicated opportunity for each Justice to speak, it would offer an open forum for any Justice and better ensure representation of the voices of each of the Justices who choose to speak. Most importantly, it would protect the Court from the criticism that the most fundamental role of oral argument-showing the Court to be a neutral, fair institution-has been undermined. We have shown that criticism to be fair based on its initial experiment in telephonic oral argument, but this bias does not need to continue.

One final aspect of the choice to switch to this particular form of oral argument demands reflection. The Justices of the Supreme Court did not make this choice, Chief Justice Roberts did-he decided that the Court would meet by telephone conference, and he decreed that there would not be a free-ranging conversation, but rather each Justice would speak in order of seniority, starting with himself. ${ }^{258}$ The power to make these decisions rests not on any constitutional provision but on norms; but if the Trump era has taught us anything, it is that even cherished norms that were presumed inviolable can fall by the wayside in the face of partisanship, political expediency, and extreme political polarization. ${ }^{259}$

${ }^{257}$ Id. (reporting negotiations on this issue between Chief Justice Rehnquist and Oyez founder Jerry Goldman, and republishing the fax from the Chief agreeing to make the recordings and transcripts available each week).

${ }^{258}$ Biskupic, supra note 6.

259 See, e.g., Tom McCarthy, Donald Trump and the Erosion of Democratic Norms in America, GUARDIAN (June 2, 2018) https://www.theguardian.com/us-news/2018/jun/02/trump-department-ofjustice-robert-mueller-crisis (reporting interviews with former assistant attorneys general, law professors, and analysts "from across the political spectrum" describing the undermining of democratic norms and previously entrenched institutions). 
